\title{
Role of the host genetic variability in the influenza A virus susceptibility
}

\author{
Ana Carolina Arcanjo ${ }^{*}$, Giovanni Mazzocco ${ }^{2,3 *}$, Silviene Fabiana de Oliveira ${ }^{1,4}$, Dariusz \\ Plewczynski2,4,5,6 and Jan P. Radomski2,7凶
}

1Laboratório de Genética, Departamento de Genética e Morfologia, Instituto de Ciências Biológicas, Universidade de Brasília, Brasília, DF, Brazil; IInterdisciplinary Center for Mathematical and Computational Modeling, Warsaw University, Warsaw, Poland; 3Institute of Computer Science, Polish Academy of Sciences, Warsaw, Poland; ${ }^{4 T h e}$ Jackson Laboratory for Genomic Medicine, c/o University of Connecticut Health Center; Farmington, CT USA; ${ }^{5}$ Yale University, New Haven, CT, USA; ${ }^{6}$ Center for Innovative Research, Medical University of Bialystok, Poland; ${ }^{7}$ Institute of Biotechnology and Antibiotics, Warsaw, Poland

The aftermath of influenza infection is determined by a complex set of host-pathogen interactions, where genomic variability on both viral and host sides influences the final outcome. Although there exists large body of literature describing influenza virus variability, only a very small fraction covers the issue of host variance. The goal of this review is to explore the variability of host genes responsible for host-pathogen interactions, paying particular attention to genes responsible for the presence of sialylated glycans in the host endothelial membrane, mucus, genes used by viral immune escape mechanisms, and genes particularly expressed after vaccination, since they are more likely to have a direct influence on the infection outcome.

Key words: Influenza A virus, host-pathogen interactions

Received: 21 May, 2014; revised: 13 August, 2014; accepted: 28 August, 2014; available on-line: 04 September, 2014

\section{INTRODUCTION}

Influenza virus is one of the most important cause of infections of the respiratory tract, with 3-5 million clinical infections and 250000-500000 fatal cases annually (Dawood et al., 2012; Simonsen et al., 2013; WHO, 2014). Immunity to influenza virus infection has been a research topic for more than 70 years (Andrewes, 1939) due to the relevant impact the illness has on global health care. Although some aspects of the immunological response to influenza are well understood, there are still many open research questions in this field.

The influence of viral genetic variability on infection is undoubtedly the most important and heavily investigated topic (Hatta et al., 2001; Wagner et al., 2002; Uipraserktul et al., 2005; Gambaryan et al., 2006; Bateman et al., 2008; Nicholls et al., 2008; Das et al., 2010; Jayamaran et al., 2012; Sriwilaijaroen \& Suzuki, 2012; Thakaramaran et al., 2012; Guarnaccia et al., 2013; Koel et al., 2013; Sun et al., 2013; Thakaramaran et al., 2013; El Moussi et al., 2014; Qi et al. 2014; Su et al., 2014). The high antigenic drift rate observed in the influenza virus is one of the primary reasons why constantly updated seasonal influenza vaccination is recommended. Genomic variability of the influenza virus has been largely investigated over the years, yet the variability of the host remains a sparsely documented topic, despite its crucial impact on the immune response (Wijburg et al., 1997; Matrosovich \& Klenk, 2003;
Schmitz et al., 2005; Jayasekera et al., 2007; Koyama et al., 2007; Throsby et al. 2008; Ichinohe et al., 2009; Sabbah et al., 2009; Kreijtz et al., 2011; Zhou et al., 2012; Henn et al., 2013; Hertz et al., 2013; Lin \& Brass, 2013) and the course of infection. The goal of this review is to explore genomic variability in the host genes that mediate hostpathogen interactions. Implemented genomic approach focuses on the major gene variants found in the 1000 Genomes Project data (the 1000 Genomes Project Consortium, 2010; Clarke et al., 2012), and is aimed at understanding how much variability is present across different human populations, and at identifying conservation level of such genes. We attempted to predict whether the genetic variants found in large human populations affect the specificity of virus binding and subsequent effectiveness of the immune response. Genes related to virus entry into the host cell are responsible for the production and assembly of Neu5Ac- $\alpha 2,6-G a l \beta 1,4-G l c N A c$ (human), and the Neu5ac- $\alpha 2,3-G a 1 \beta 1,4-G l c N A c$ (avian) receptors in the host membrane. Both the human and avian influenza A virus receptor proteins, hemagglutinin (HA) and neuraminidase (NA), interact with the above glycans at the beginning of infection. Sialic acid composition and

\section{e-mail: janr@icm.edu.pl}

*Both authors contributed equally

Abbreviations: ADCC, antibody-dependent cell-mediated cytotoxicity; AM, alveolar macrophage; APC, antigen-presenting cell; ASC, apoptosis-associated speck-like protein; ASL, airway surface liquid; C1QBP, component 1 binding protein; CARD, caspase activation and recruitment domain; CD32, cell surface receptor; CD55, gene, decay-accelerating factor 55; CMAS, gene, cystidine monophosphate $\mathrm{N}$-acetylneuraminic acid synthase; CMP, cystidine monophosphate; CRD, carbohydrate recognizing domain; CTD, Cterminal domain; CTL, cytotoxic T lymphocyte; DC, dendritic cell; DDX58, gene, encodes RIG-I; DHX58, gene, encodes LGP2; DNAJC3, gene, encodes P58IPK; EIF2AK2, gene, encoded PKR; ER, endoplasmic reticulum; HLA, human leukocyte antigen; human version of the major histocomatibility complex (MHC); IAV, influenza A virus; IFIT, interferon-induced proteins with tetratricopeptide; IFN, interferon; IgA, immunoglobulin $A$; IgG, Immunoglobulin $G$; IgM, immunoglobulin M; LGP2, laboratory of genetics and physiology 2 protein; LRR, leucine-rich-repeat; MAVS, mitochondrial antiviralsignaling protein; MUC, gene, mucin; NBD, nucleotide-binding domain; Neu5Ac, sialic acid (also known as neuraminic acid or $\mathrm{N}$-acetylneuraminic acid); NK, natural killer cell; NLR, NOD-like receptor; NOS2, nitric oxide synthase 2; NP, influenza virus nucleoprotein; PAMP, pathogen-associated molecular pattern; PKR, ssRNAbinding protein kinase; PRR, pattern recognition receptor; PYD, pyrin domain; RIG-I, retinoic acid-inducible gene I product; RLR, RIG-I-like receptor; RPAIN, replication protein A interacting protein; SLC35A2, gene, solute carrier family 35 type A2; ST3GAL, gene, sialyltransferase that binds sialic acid to a 2,3 positioned galactose; ST6GAL, gene, sialyltransferase that binds sialic acid to a 2,6 positioned galactose; TAP, transporter of antigen processing; TCR, T-cell receptor; TLR, toll-like receptor; TNF, tumor necrosis factor; TRIM25, tripartite-motif-containing protein 25; VISA, gene, encodes MAVS. 


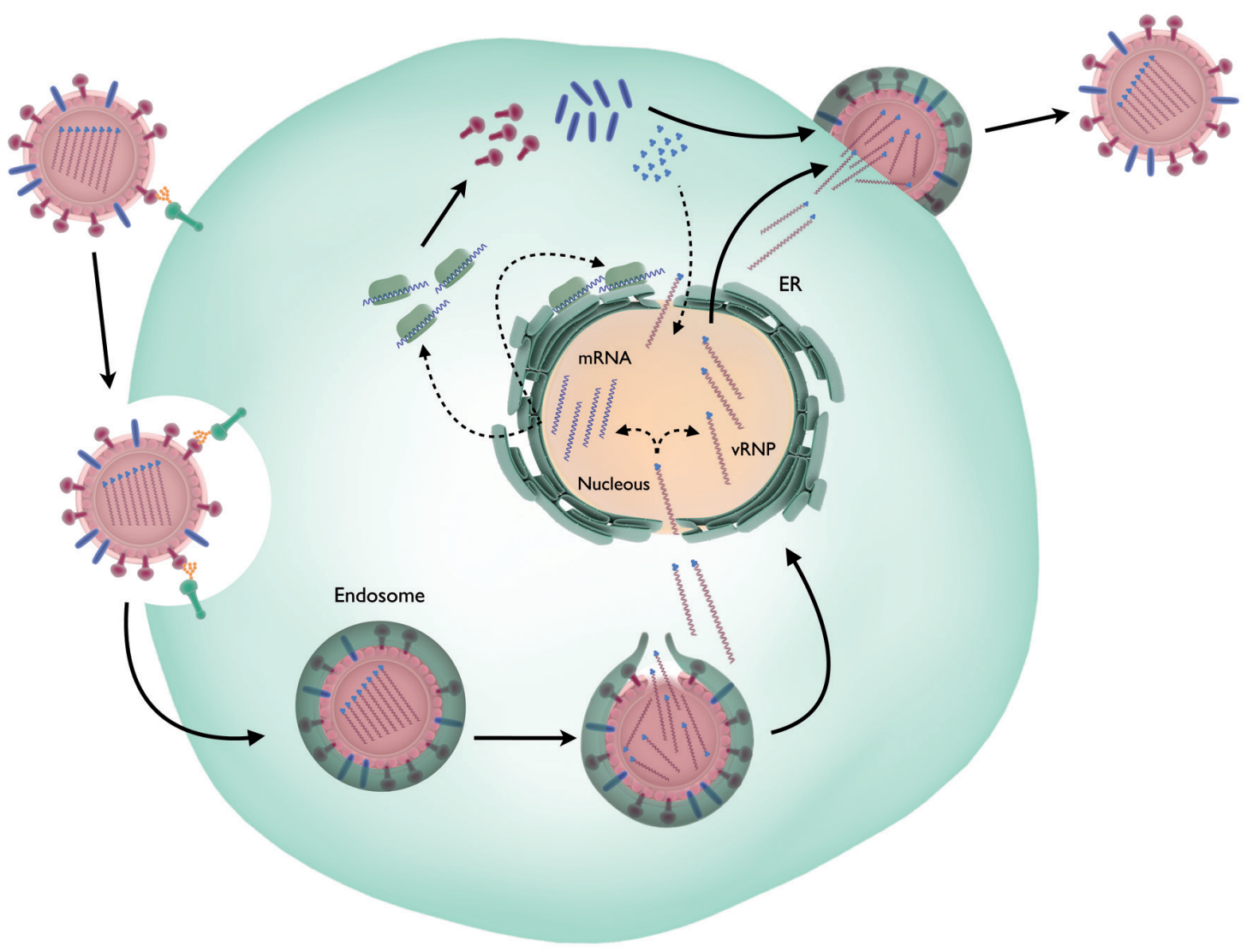

Figure 1. Influenza virus life cycle

During the first step of influenza virus infection, the viral glycoprotein HA binds to the receptors on the host cell surface. The virus is then internalized via endocytosis. The low endosomal $\mathrm{pH}$ triggers a conformational change in the $\mathrm{HA}$, leading to the fusion of the virus with endosomes and the consequent release of viral ribonucleoprotein complexes (vRNPs) in the cytoplasm. The vRNPs are transported into the nucleus, where both mRNA transcription and vRNA replication/new vRNPs assembly occurs. Translation of viral mRNAs takes place differently in both cytoplasm and endoplasmic reticulum (ER). Following the post-translational modifications (PTM) of certain viral proteins, the structural components of the viral particle are transported to the plasma membrane along with new vRNPs, where viral assembly and virus budding take place.

modifications of amino acids near the binding site for $\mathrm{HA}$, and the subsequent site of interaction with NA, influence the success of infection.

\section{VIRUS BINDING TO CELL}

The human influenza virus attaches to the host cell by binding to Neu5Ac- $\alpha 2,6-G a l-\beta 1,4-G l c N A c$ (2,6-linked, in short), a sialic acid modification to glycans that is extremely abundant in humans, especially in the epithelial cells of the upper respiratory tract (Skehel \& Wiley, 2000). The mucin that protects the cells in the human upper respiratory tract is equally enriched with Neu5Aca2,3-Gal (2,3-linked; Cohen et al., 2013), which is recognized by avian strains of influenza virus (Cone, 2009). Both types of sialylglycans are present in different proportions at different regions of the human respiratory tract, and are essential for success of the infection by influenza A (Shynia et al., 2006; Nicholls et al., 2007).

Sialyltransferases are responsible for adding Neu5Ac moiety to the glycans (Cohen \& Varki, 2010). Twenty genes coding for sialyltransferase were described in the human genome (Harduin-Lepers et al., 2005). Both $\alpha 2,3$ sialyltransferases (ST3GAL1 to 6) and $\alpha 2,6$ sialyltransferases (ST6GAL1 and 2) are responsible for the sialylation of glycans in the human cell membrane. Some of these genes are expressed only in specific tissues, and different sialyltransferases bind the Neu5Ac to different substrates. For example, ST6GAL1 adds the sialic acid moiety in the $\alpha 2,6$ position to the type-II glycans (Galß1,4GlcNAc) that are $N$-linked, and sometimes to O-linked glycoproteins as well. In contrast, ST6GAL2, which is expressed only in brain and fetal tissues, adds the sialic acid in the $\alpha 2,6$ position to oligossaccharides, but not to proteins (Glaser et al., 2007). Therefore, we selected ST6GAL1, ST3GAL1, ST3GAL2, ST3GAL4 and ST3GAL5 genes as relevant for this review, since those are expressed in the human respiratory tract (Kitagawa \& Paulson, 1994; Harduin-Lepers et al., 2001; Glaser et al., 2007).

In order to analyze mechanisms and mutations that can confer complete cell immunity to influenza viruses, the insertional mutagenesis assays were developed in a human cell line (haploid for all chromosomes except chromosome 8). They showed that three independent insertions in the SLC35A2 gene, and two in the CMAS gene are associated with complete cell immunity to influenza viruses (Carette et al. 2009). CMAS encodes the enzyme that binds Neu5Ac to a cystidine monophosphate residue. The sialyltransferases cannot transfer Neu$5 \mathrm{Ac}$ into an acceptor unless it is bound to a CMP residue, because free Neu5Ac cannot be transported to the Golgi membrane (Fleischer, 1998; Munster et al., 1998). SLC35A2 encodes the solute carrier-family 35 transport- 
Table 1. List of variants for seven genes involved in virus binding

\begin{tabular}{|c|c|c|c|c|c|c|c|c|}
\hline Type of variant* & CMAS & SLC35A2 & ST3GAL1 & ST3GAL2 & ST3GAL4 & ST3GAL5 & ST6GAL1 & Total \\
\hline Frameshift coding & 0 & 4 & 0 & 2 & 4 & 0 & 0 & 10 \\
\hline Non-synonymous coding & 3 & 14 & 4 & 2 & 7 & 11 & 0 & 41 \\
\hline Splice Site & 3 & 0 & 4 & 2 & 8 & 5 & 1 & 23 \\
\hline Synonymous coding & 1 & 2 & 10 & 2 & 17 & 0 & 9 & 41 \\
\hline Intronic & 20 & 30 & 27 & 24 & 67 & 83 & 7 & 258 \\
\hline $5^{\prime}$ UTR & 1 & 1 & 21 & 17 & 1 & 6 & 2 & 49 \\
\hline 3'UTR & 2 & 10 & 12 & 32 & 6 & 82 & 54 & 198 \\
\hline Upstream & 1 & 0 & 0 & 1 & 3 & 5 & 0 & 10 \\
\hline Downstream & 2 & 2 & 10 & 2 & 1 & 4 & 2 & 23 \\
\hline Total Number of Variants & 33 & 63 & 88 & 84 & 114 & 196 & 75 & 653 \\
\hline
\end{tabular}

The genetic variants described in the 1000 Genomes Project Pilot data are: Frameshift coding: structural mutation in the coding sequence, resulting in a frame shift of reading ( $A, B)$; Non-synonymous coding: nucleotide substitution in the coding sequence ( $A$, $B$ ), resulting in an amino acid change in the peptide chain $(A, C)$; Splice Site: 1-3bp into an exon or 3-8bp into an intron (A); Synonymous coding: nucleotide substitution in the coding sequence $(A, B)$, but not resulting in an amino acid change $(C)$; Intronic: mutation in intron (A); $5^{\prime} U T R$ : in $5^{\prime}$ untranslated region (A, B); $3^{\prime} U T R$ : in $3^{\prime}$ untranslated region $(A, B)$; Upstream: mutation within $5 \mathrm{~kb}$ upstream of the $5^{\prime}$ end of transcript $(A)$; Downstream: mutation within $5 \mathrm{~kb}$ downstream of the $3^{\prime}$ end of transcript $(A)$.

er type A2, responsible for transporting CMP-Neu5Ac from the cytoplasm to the Golgi membrane.

The glycan receptors are important in cell signaling and adhesion; therefore, they are important for the cell's life cycle. Considering the fundamental role of genes coding for the production of the glycan receptor in susceptibility to influenza, we decided to verify whether the lack of expression of these genes causes any known human disease. Indeed, a malfunction of the SLC35A2 gene is followed by a severe disease: congenital disorder of glycosylation type IIm ( $\mathrm{Ng}$ et al., 2013). Defects arising from deficient SLC35A2 expression are severe and include developmental delays, hypotonia, variable ocular anomalies, variable brain malformations associated with an unusual serum transferrin profile, seizures, hypsarrhythmia, poor feeding, microcephaly, recurrent infections, dysmorphic features, shortened limbs, and coagulation defects ( $\mathrm{Ng}$ et al., 2013). All subjects showed diminished proportions of sialic acid glycoconjugates. The profound phenotype and short life span in these patients suggests that malfunctioning of SLC35A2 and/or CMAS is incompatible with life. Therefore, the influenza virus binds to an essential host receptor.

We examined whether variability of the genes responsible for production and assembly of the sialylglycan are indeed more changeable, by searching for the variants described for those genes in the 1000 Genomes ENSEMBL Browser during the pilot phase of the project (1000 Genomes Consortium, 2010). The genes length ranged from $8.8 \mathrm{~Kb}$ (SLC35A2) to $148 \mathrm{~Kb}$ (ST6GAL1), with the latter showing 0.5 variants per $\mathrm{Kb}$, whilst the first showed 7.2 variants per $\mathrm{Kb}$. Most of the variants found in any of the analyzed genes were mutations in intronic regions (29-66.7\% of described variants), except for the ST6GAL1 gene, for which $72 \%$ of variants were located in the 3'UTR region, with $9 \%$ variance (c.f. Table 1).

SLC35A2 showed both non-synonymous and frameshift coding variants, which could potentially alter the phenotype of the resulting protein. Interestingly, SLC35A2 was the only gene examined in which malfunction causes a severe and ultimately lethal congenital disorder and the absence of a functional copy of the gene causes severe developmental defects $(\mathrm{Ng}$ et al.,
2013). Nevertheless, considering the crucial importance of CMP-Neu5Ac transport from the cytoplasm to Golgi apparatus, some studies have shown that SLC35A3 (which is an UDP-Gal/UDP-GlcNAc transporter) can help in transporting of CMP-Neu5Ac in cases where SLC35A2 is working poorly (Olczak et al., 2013). None of the two insertions in the CMAS gene nor the three insertions in the SLC35A2 gene described by Carette et al. (2009) were found in the screening of the $1000 \mathrm{Ge}$ nomes Project data.

Several articles reported a change in binding affinity of the HA molecule to the host receptor that are related to amino acid changes in the structure of HA, which cause a conformational change in the receptor binding site of the protein (Ohuchi et al., 1997; Matrosovich et al., 2000; Hatta et al., 2001; Gambaryan et al., 2006; Bateman et al., 2008; Tria et al., 2013). The binding of influenza A avian virus (IAV) HA to the sialylglycan ( $\alpha 2,3$ or $\alpha 2,6$ linked) is rather weak $\left(K_{\text {diss }}>10^{-4} \mathrm{M}\right)$. As at result, successful entry of a virus into a cell is facilitated when several HAs bind to several sialylglycans (Matrosovich \& Klenk, 2003). If any variant of the analyzed genes affects the availability or the quantity of sialylglycans on the cell surface, it will also affect the success rate of cell infection. In this context, it is known that the topology and density of glycans in the membrane as well as time of incubation are also involved in the successful binding of proteins to glycans (Lewallen et al., 2009), and that the differences in specificity of binding of avian and human influenza virus rely not only on $\alpha 2,3$-linked or $\alpha 2,6$-linked sialic acid binding, but also on differences in the structure of the sialylated glycans. Human-like strains of influenza virus bind to glycans that display an open-umbrella shape, which is formed by $\alpha 2,6$ sialic acids bound to the long chains of oligossaccharides. On the other hand, avian strains of influenza virus HA bind to $\alpha 2,3$ or $\alpha 2,6$ sialic acid only if they are bound to the short chains of oligosaccharides, in a cone shape (Chandrasekaran et al., 2008).

The binding of influenza virus and viral entry into a cell (Fig. 1) are two early steps during the virus-host interaction, in which human genetic variability can either predispose or protect from infection. How the virus accesses the cell and the numerous host mechanisms preventing virus infection are also subject to the genetic 
changes. One host gene that protects against influenza infection is CD55, coding for a protective decay-accelerating factor that prevents cell damage caused by complement molecules (Osuka et al., 2007). The CD55 gene is expressed in all types of cells in the two forms: a GPImembrane anchored form (mCD55), which is particularly well expressed in the plasma membrane of all blood tract cells, and a soluble form (sCD55) found in body fluids (Medof et al., 1987). The CD55 is associated with prevention of lung lesions, being largely expressed in this type of tissue (Osuka et al., 2007). A SNP (rs2564978) on the promoter region of the CD55 gene was found to be associated with severe influenza A H1N1 pandemic 2009 infection in Chinese and Japanese individuals. The rs2564978T/T genotype was found to be highly associated with severe form of influenza, while the rs2564978C/C was associated with a less severe form (Zhou et al., 2012). When searching the frequency of this SNP in the 1000 Genomes Project database, we found that $\mathrm{rs} 2564978 \mathrm{~T}$ is more frequent in Chinese populations (54\% in Chinese from Beijing and 63\% in Southern Han Chinese), while in other populations its frequency ranged from 1.7\% (Yoruba from Ibadan) to 39\% (Japanese from Tokyo). Despite the higher frequency of the protective alleles in Yoruba, the African population was the one that suffered the most from the spread of the influenza A H1N1 2009 pandemic, with a relative death rate of 7.8 deaths per 100000 habitants in the first 12 months of circulation of the virus (Dawood et al., 2012). The second severely affected population was the Southern Asians, ranging from 3.3 deaths per 100000 habitants (considering only respiratory failure), to 4.4 deaths per 100000 habitants (considering both respiratory and cardiovascular failures associated with influenza). Europeans and Western Pacific individuals showed the smallest rates of deaths per 100000 habitants (1.8 and 1.7, respectively), and indeed those populations have the highest frequencies of the protective $\mathrm{C}$ allele (70-90\%).

\section{The protective properties of mucus against Influenza A Viruses}

Epithelial mucus is a dynamic semipermeable barrier that enables exchange of nutrients, water, gases, odorants, hormones and gametes while being impermeable to most bacteria and many pathogens (Cone, 2009). It is present in the respiratory tract, where it is called Airway Surface Liquid (ASL) and constitutes a primary innate barrier to foreign molecules and pathogens (Lillehoj \& Kim, 2002). The ASL consists of a strictly regulated mixture of water, salts and various macromolecules such as mucins, proteoglycans, lipids, and other proteins that confer viscosity and defensive function to ASL. Whenever one of these components is missing, or is present at suboptimal concentrations, there is a large probability of disease such as asthma and other respiratory diseases (Lillehoj \& Kim, 2002). ASL is rich in $\alpha 2,3$-linked and $\alpha 2,6$-linked moieties, both in secreted and membranebound forms (Nicholls et al., 2007).

It was suggested that mucins are the most important components of ASL, because of their high concentrations in the secreted portion of the mucus and high number of genes encoding both membrane-bound and secreted forms of mucins expressed in the human genome. Thirteen mucin-encoding genes were described in the human genome, eight of which are expressed in the respiratory tract - products of the five are secreted, and of the three remaining are membrane-bound (Lillehoj \& Kim, 2002). Mucins are high-molecular-weight glycopro- teins containing variable numbers of amino acid tandem repeats enriched in Ser, Thr and Pro residues (Voynow et al., 1998; Ogasawara et al., 2007). The presence of these repetitive amino acids is responsible for heavy glycosylation, and thus polydispersity in both size and charge of mucin molecules. Glycosylation takes place between the Ser/Thr moieties of the peptide backbone and N-acetylgalactosamine of the oligosaccharides, that is characteristic of O-linked glycoproteins (Lillehoj \& Kim, 2002; Rose \& Voynow, 2006). 95\% of all secreted mucins are the MUC5 type, which is heavily O-glycosylated (Lillehoj $\&$ Kim, 2002) and is acceptor of both $\alpha 2,3$-linked and $\alpha 2,6$-linked sialic acids. The sialic acid bound to these mucins is responsible for the lubricant and high viscosity features of the mucus (Nicholls et al., 2012, Varki \& Gagneux, 2012). MUC2 is a secreted form of the protein that comprise $2.5 \%$ of mucins in the ASL (Kirkham et al., 2002; Rose \& Voynow, 2006) containing about 40\% sialylated oligosaccharides (Karlsson et al., 1997). MUC2 expression is heavily upregulated during inflammatory processes or infection, mainly due to activation by IL-4 and IL-9 (Lillehoj \& Kim, 2002). The ASL contains also other defense-related proteins, such as protease-inhibitors, anti-oxidants, proteases, anti-microbial proteins, IgA and cytokines (Lillehoj \& Kim, 2002). The high concentrations of $\operatorname{IgA}$ in the mucus are indicative of an early infection, suggesting that antibodies and immunoglobulins are secreted in the mucus to fight the initial phases of infection (Kreijtz et al., 2011).

Some proteases were shown to activate influenza virus, and are possibly responsible for the pneumopathogenicity of the virus (Lillehoj \& Kim, 2002). Mucins showing anti-protease activity (Nadziejko \& Finkelstein, 1994), seem to improve the host defense system. Nicholls et al. (2007) hypothesized that the high content of sialylated proteins in the secreted mucus is a physical barrier to the influenza virus, preventing the virus from accessing target epithelial cells. The physiological role of cellular sialic acid receptors is to promote mucus adherence to the epithelial cell surface that protects epithelial tissues from dehydration, microbial pathogens, and reactive oxygen species produced by infectious bacteria and/ or the oxidative burst of leucocytes (Ogasawara et al., 2007). However, sialoglycoproteins mediating the cell adherence and viscoelasticity of mucus, and serve as receptor sites for the binding of exogenous macromolecules, including influenza virus HA.

The mucus line of defense comprises a viscoelastic gel up to $50 \mu \mathrm{m}$ thick, immobilizing bacteria and viruses, that are then cleared by the cilia action of ciliated cells of the respiratory tract. The enhanced defence is probably also due to the soluble sialylated proteins in the mucus, that mimic the natural ligands of influenza on the cell surface, which immobilize virus on the mucus layer (Duez et al., 2008; Cohen et al., 2013). They found that the higher the concentration of sialic acids in the mucus, the less epithelial cells were infected in vitro, especially if the mucus samples are treated with the neuraminidase (NA) inhibitor oseltamivir phosphate. The virus could find its way through the mucus layer towards epithelial cells in the absence of oseltamivir, since NA is able to free the virus entangled in mucus by disrupting the binding of the virus HA to sialic acid. The rate of virions clearance depends on the interactions of motile cilia from the trachea with the overlaying mucus. It is not yet clear what determines the rates of mucociliary clearance, which vary within proximal and distal regions of the airways. Certainly, the effeicacy of cilia are primary determinants of the basal mucociliary clearance rate, but the quantity and 


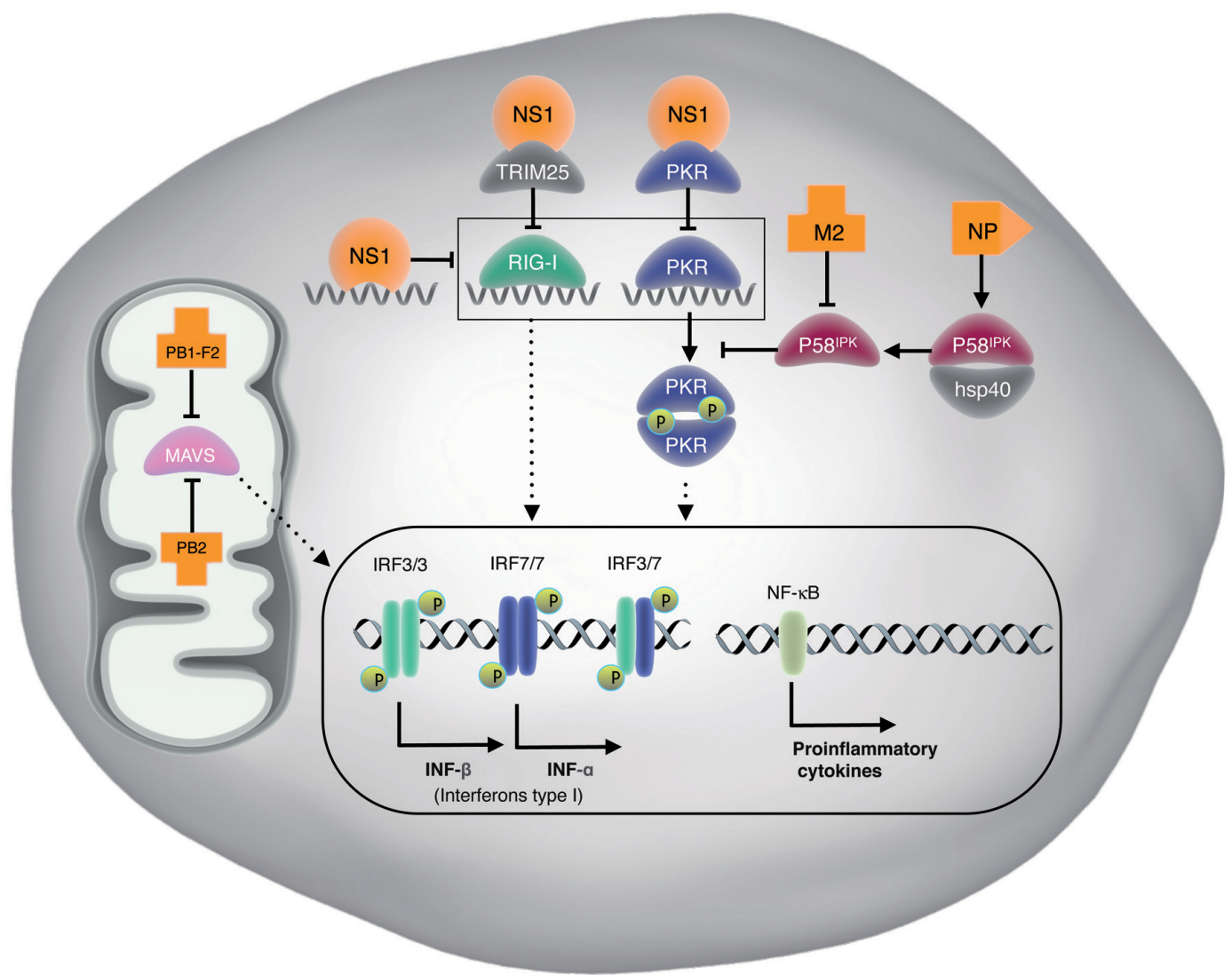

Figure 2. Escape from adaptive response.

Upon influenza virus infection, viral RNA is sensed and several pathways are activated. This results in the production of type-I interferons, pro-inflammatory cytokines and induction of an antiviral state. Influenza virus proteins interact with this pathway. NS1 binds viral RNA to mask detection by PRRs. It blocks RIG-I activation by binding TRIM25 and also binds PKR and inhibits its phosphorylation, which occurs when PKR binds viral RNA. NP interacts with the P58IPK/hsp40 complex upon which P58ipk is dissociated from the complex and inhibits the phosphorylation of PKR. M2 on the other hand restores the P58IPK /hsp40 complex resulting in the inhibition of protein synthesis and induction of cell apoptosis, facilitating the release of virus particles. PB1-F2 binds mitochondrial antiviral signaling protein (MAVS), thereby inhibiting this protein and type-I interferon production. PB2 also binds MAVS and inhibits its function. Furthermore, PB2 binds interferon promoter stimulator 1 (IPS-1), resulting in inactivation of the promoter that would lead to production of type I interferon. Dotted arrows represent pathways and solid lines and arrows represent direct interactions.

viscoelastic properties of mucin may also be important variables (Knowles \& Boucher, 2012).

Moreover, proteins with CRDs are also likely to interact with $\mathrm{HA}$ and NA, since those two viral proteins have $N$-linked oligossaccharides side chains. Yang et al. (2011) showed that Galectin-1 can bind influenza virus and inhibit viral infection both in vitro and in mice. The authors observed that the galectin-1 expression is upregulated in animals during ongoing infection in a viralload-dependent manner (the larger the viral load, the more galectin-1 expressed). Also, mice that were infected with a neurovirulent strain of influenza A virus showed a higher rate of survival when treated with galectin-1 intranasally, and with a lower degree of apoptosis and inflammation in the lungs, showing that galectin-1 is an effective inhibitor of viral reproduction and reduces the symptoms of infection.

\section{INSIDE A HOST CELL: INNATE IMMUNE RESPONSE TO INFLUENZA VIRUS INFECTION.}

The innate immune system constitutes the first line of defense against a viral infection (Fig. 2). During this phase, epithelial host cells can recognize novel influenza infection via pattern recognition receptors (PRRs).
PRRs recognize pathogen-associated molecular patterns (PAMPs) expressed during virus replication (Hale et al., 2010). The principal PAMP for influenza is the viral RNA bearing a 5'-triphospate group (PPP-RNA), which constitutes a molecular signature that distinguishes foreign RNA from host RNA (Abbas et al., 2013). The receptors able to sense the viral RNA are: toll-like receptors (TLRs), RIG-I-like receptors (RLRs), NOD-like receptors (NLRs) (Pang \& Iwasaki, 2011), and interferoninduced proteins with tetratricopeptide repeats (IFITs, Abbas et al., 2013).

The major function of these receptors is to initiate expression of pro-inflammatory cytokines and type-I interferons: IFN- $\alpha$ and IFN- $\beta$ (Heil et al., 2004; Lund et al., 2004), that are able to inhibit protein synthesis in host cells, limiting the replication of viruses. They also stimulate dendritic cells (DCs) to enhance both CD4+ and $\mathrm{CD} 8+$ antigen presentation, thus promoting activation of the adaptive immune response (Kreijtz et al., 2011). The innate cellular response to viral infection is mainly carried out by macrophages and DCs. Alveolar macrophages (AM) have somewhat opposing effects after becoming activated in the host's lungs. On the one hand, they phagocytose influenza virus-infected cells, thus limiting viral spread (Tumpey et al., 2005; Kim et al., 2008); and on the other, they produce nitric oxide 
synthase 2 (NOS2) and tumor necrosis factor alpha (TNF- $\alpha$ ), thus contributing to influenza virus-induced pathology (Jayasekera et al., 2007; Lin et al., 2008). These competing effects clearly underscore the delicate equilibrium that exists within the immune system. Another $\mathrm{AM}$ role is in regulating the immune response, especially in the development of antigen-specific T-cell immunity (Wijburg et al., 1997). Of note, while AM produce only low levels of pro-inflammatory cytokines (van Riel et al., 2011), blood-derived macrophages infected with influenza viruses produce large amounts of pro-inflammatory cytokines.

\section{Receptors I: Toll-like receptors (TLR)}

Toll-like receptors (TLRs) are a highly conserved family of PRRs glycoproteins and play a pivotal role in the innate immune recognition of viruses (Fig. 2). TLRs consist of an N-terminal extracellular PAMP-binding domain with multiple leucine-rich repeats (LRRs) linked by a transmembrane domain to a cytosolic C-terminal intracellular signaling domain called Toll/IL-1R homology (TIR). TIR domain is named after its similarity to the intracellular domain of the interleukin-1 receptor (IL1R) that mediates down-stream signaling events upon activation of the receptor (Jensen \& Thomsen, 2012). TLR activation triggers a signal cascade involving adaptor proteins, protein kinases, and effector transcription factors, and mainly results in the production of type I IFN (e.g., IFN-beta). These processes induce an antiviral cellular state, providing an important first line of defense against virus infection. Others TLR-triggered proinflammatory cytokines (e.g. TNF and IL-6) are also important determinants of the balance between beneficial host innate immune responses and immunopathology.

Ten known TLR (TLRs 1-10) have been identified in humans. Among them TLR3, 7, 8 and 10 are known to recognize influenza virus infection (Koyama et al., 2007; Le Goffic et al., 2007; Lee et al., 2014). TLR7 and TLR8 share the highest degree of sequence similarity and sense ssRNA oligonucleotides containing guanosine and uridine-rich sequences. TLR7 is preferentially expressed in the endosomes of plasmacytoid dendritic cells (pDCs) and $\mathrm{B}$ cells, while TLR8 is preferentially expressed in myeloid DCs and monocytes. Upon stimulation, TLR7 and TLR8 recruit a TIR-containing adaptor named myeloid differentiation primary response gene 88 (MyD88) to the cytoplasmic TIR domain of the receptor (Medzhitov et al., 1998). This signaling pathway leads to the activation

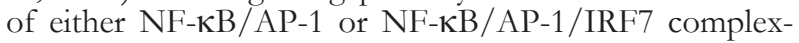
es, which result in the transcription of proinflammatory cytokines and INF- $\alpha$ genes, respectively. TLR3 is localized in the intracellular compartment of macrophages, B lymphocytes, and DCs. It is located both intracellularly and on the surface of NK cells, epithelial cells, and fibroblasts. It recognizes viral dsRNA expressed in some viruses, leading to the activation of $\mathrm{NF}-\mathrm{\kappa B} / \mathrm{AP}-1 /$ IRF3 complexes and upregulation of IFN- $\beta$ (Jensen \& Thomsen, 2012). Recent studies reported an upregulation of human TLR10 expression upon influenza H5N1 viral infection, especially in primary macrophages. These data suggest that TLR10 is able to substantially enhance vRNP-induced activation of IL-8 expression (Lee et al., 2014).

\section{Receptors II: RIG-I-like receptors (RLRs)}

The RIG-I-like receptors (RLRs) are cytosolic proteins that recognize viral RNA and are expressed by most human cell types (Fig. 2). They share a con- served domain structure, characterized by a central DExD/H-box helicase domain and a ssRNA/dsRNA (ss/dsRNA)-binding C-terminal domain (CTD) which, when unbound, functions as a repressor domain (RD) (Gack, 2014). Three RLRs are known to be directly implicated in viral recognition: the retinoic acid-inducible gene I product (RIG-I, encoded by the DDX58 gene), the laboratory of genetics and physiology 2 (LGP2, encoded by the DHX58 gene) and the melanoma-differentiation-associated antigen 5 (MDA5). RIG-I and MDA5 harbor two N-terminal caspase activation and recruitment domains (CARDs) which, upon virus sensing, initiate downstream signaling, eventually leading to type I IFN gene expression. In contrast, LGP2 lacking the CARD signaling module has been shown to exert a regulatory role in RLR signaling, although its precise mechanism of action is still largely unknown (Kato et al., 2006). RIG-I and LGP2 have been reported to play an important role in influenza virus RNA recognition, yet MDA5 recognizes also the viral RNA of other pathogens (Jensen \& Thomsen, 2012). Recent studies revealed that RIG-I activity is tightly regulated by post-translational modifications; in particular, the dephosphorylation of CTD (Thr770, Ser854/855) and CARD (Ser8, Thr170) and their subsequent poly-ubiquitination at Lys63 and Lys172, respectively. Ubiquitin-bound CARDs facilitate RIG-I oligomerization and binding to MAVS, ultimately inducing antiviral signaling. (Gack, 2014).

\section{Receptors III: NOD-like receptors (NLRs)}

Nucleotide-binding oligomerization domain-containing (NOD)-like receptors (NLR) are cytosolic proteins involved in the regulation of inflammatory and apoptotic responses, in particular during anti-viral responses (Fig. 2). NLRs contain a leucine-rich-repeat (LRR) domain located at the $\mathrm{C}$-terminus and which is considered to be the RNA sensing region. The central NACHT domain mediates oligomerization and activation, while the N-terminal effector-binding domain, often a CARD or pyrin domain (PYD), upon activation and oligomerization of the whole NLR triggers the signal transduction cascade (Fritz et al., 2006). Among NLRs, both NLRC2 (also named NOD2) and NLRP3 are involved in influenza virus RNA-sensing.

NLRC2, which contains two CARD domains at the $\mathrm{N}$-terminus (Ogura et al., 2001), is a NOD-like receptor family member that was recently shown to recognize ssRNA species derived from either one of RSV, parainfluenza virus and influenza A virus. Upon viral ssRNA recognition, NLRC2 associates with MAVS (encoded by the VISA gene) through an interaction dependent on the LRR and nucleotide-binding domains (NBDs). This initiates the MAVS-dependent pathway (similar to the RLRs mechanism previously indicated) culminating with the expression of type-I IFN and proinflammatory cytokines. In contrast to RLRs, the NLRC2 interaction with MAVS doesn't involve CARD-CARD binding (Sabbah et al., 2009). NLRP3 (for NOD-like receptor family pyrin domain-containing 3 ) contains a pyrin domain (PYD) that can interact with the N-terminal PYD domain of apoptosis-associated speck-like protein (ASC) containing a CARD domain. NLRP3 oligomerizes and recruits ASC and a procaspase-1 to form an inflammasome complex. This activates caspase-1, which subsequently mediates the conversion of pro-IL-1beta and pro-IL-18 to fully functional IL-1beta and IL-18. Activation occurs also upon infection with adenovirus, 
Table 2. Host genes involved in viral escape mechanisms. DNAJC3 (encodes the inhibitor P58IPK); EIF2AK2 (encodes PKR); TRIM25 (encodes the tripartite-motif-containing protein 25); VISA (encodes the MAVS protein)

\begin{tabular}{|c|c|c|c|c|c|}
\hline Type of variant & DNAJC3 & EIF2AK2 & TRIM25 & VISA & SUM \\
\hline Frameshift coding & 0 & 0 & 0 & 0 & 0 \\
\hline Non-synonymous coding & 2 & 15 & 4 & 16 & 37 \\
\hline Splice site & 0 & 8 & 0 & 4 & 12 \\
\hline Synonymous coding & 5 & 16 & 3 & 6 & 30 \\
\hline Intronic & 29 & 177 & 9 & 49 & 264 \\
\hline 5' UTR & 2 & 24 & 1 & 0 & 27 \\
\hline 3' UTR & 3 & 67 & 24 & 15 & 109 \\
\hline Upstream & 2 & 5 & 0 & 0 & 7 \\
\hline Downstream & 3 & 3 & 0 & 0 & 6 \\
\hline Other* & 0 & 2 & 0 & 0 & 2 \\
\hline Total number of variants & 46 & 315 & 41 & 90 & 492 \\
\hline
\end{tabular}

See the legend of Table 1 for explanations.

Sendai virus (ssRNA virus) and influenza virus A (Allen et al., 2009; Ichinohe et al., 2009).

\section{Interferon-induced proteins with tetratricopeptide repeats (IFITs)}

IFITs are effectors within the innate immune system that seem to confer virus defense via disruption of protein-protein interactions in the host translation-initiation machinery. However, IFITs can directly recognize viral RNA bearing a 5'-triphosphate group (5'-PPP-RNA). IFIT1, and IFIT5 in particular, were shown to actively and selectively bind cytosolic 5'-PPP-ssRNAs. These results were confirmed by structural analysis (Pichlmair et al., 2011; Abbas et al., 2013).

\section{Viral escape from innate immunity}

Two evolutionary processes are involved in viral evolution and in the evasion by the host immune system: antigenic drift of the influenza viral genome and the high selective pressure generated by the human immune response (Fig. 2). These escape mechanisms involve the interaction between protein viral effectors and some human targets. The influenza virus NS1 protein can bind viral RNA, masking it from TLRs/RIG-I recognition, thus inducing expression of INF type I (Garcia-Sastre, 2004; Guo et al., 2007). NS1 proteins can also inactivate RIG-I binding to the tripartite-motif-containing protein 25 (TRIM25) and inhibit the ssRNA-binding protein kinase (PKR), encoded by the EIF2AK2 gene (Tan \& Katze, 1998; Garcia-Sastre, 2004; Gack et al., 2009). In addition, both the influenza virus nucleoprotein (NP) and the ion channel protein M2 can bind and inactivate the cellular inhibitor P58IPK, encoded by the DNAJC3 gene, and the P58IPK/hsp40 complex, respectively. These effectors are both critical for the regulation of PKR, and their inactivation results in the inhibition of protein synthesis, induction of cell apoptosis, and release of newly formed virus particles (Guan et al., 2010).

Table 2 presents the variability of host genes involved in viral escape mechanisms. The EFI2AK2 (another PKR) gene is the most variable gene among the four selected viral escape genes. As expected, the majority of variation is observed in the non-coding regions. In the coding region, the majority of the observed variation derives from single mutations (synonymous and non-synonymous).

\section{Mutations related to influenza infection}

Although the variability of the genes involved in innate immune response could have an important impact on the outcome of infection, our understanding of how genetic variability correlates with susceptibility to infection is still very limited and, in general, not supported by experimental approaches.

A missense mutation (F303S) in the Toll-like receptor 3 (TLR3) gene has been linked to influenza-associated encephalopathy (IAE), a severe neurological condition (Esposito et al., 2012). F303S TLR3 receptor was shown to be less effective in activating the transcription factor, $\mathrm{NF}-\kappa \mathrm{B}$, as well as triggering downstream signaling via the IFN beta receptor (Esposito et al., 2012). An additional TLR3 SNP (rs5743313) was identified in a study of 51 children with confirmed H1N1 infection (Esposito et al., 2012). The rs5743313C/T genotype was found in 18/18 children with IAV-associated pneumonia, but significantly less frequently in children with IAV without pneumonia $(p<0.0001)$, further demonstrating the association between TLR3 and IAV pathogenicity. Searching the 1000 Genomes Project database for such TLR3 variants, we found that none of the studied individuals carried the F303S mutation. In scope of this search we were not able to confirm that individuals with the rs5743313C/T genotype went through acute pneumonia related to influenza A infection (Esposito et al., 2012). On the other hand, we were able to see that the frequencies of each allele were similar between populations, with the $\mathrm{C}$ allele having a frequency of more than $80 \%$, suggesting that around $32 \%$ of individuals in the samples could possibly have the $\mathrm{C} / \mathrm{T}$ genotype assuming that the population is in Hardy-Weinberg Equilibrium. Nonetheless, four populations of the 1000 Genomes Project were outside of this range of frequency for the $\mathrm{C}$ allele, namely-British (GBR, $\mathrm{C}=76-36 \% \mathrm{C} / \mathrm{T}$ genotype), Iberic (IBS, C $=67-44 \%$ of $\mathrm{C} / \mathrm{T}$ genotype), Puerto Ricans (PUR, $71-41 \% \mathrm{C} / \mathrm{T}$ genotype), and Toscani in Italy (TSI, C $=69-43 \% \mathrm{C} / \mathrm{T}$ genotype), which indicates that those populations could be more susceptible to a more 
Table 3. List of variants within genes involved in the innate immune response to influenza virus infection (the data retrieved from the 1000 Genomes Project database)

\begin{tabular}{|c|c|c|c|c|c|c|c|c|c|c|c|}
\hline Type of variant & DDX58 & DHX58 & NLRP3 & NOD2 & IFIT1 & IFIT5 & TLR3 & TLR7 & TLR8 & TLR10 & SUM \\
\hline Frameshift coding & 3 & 1 & 0 & 2 & 1 & 0 & 1 & 1 & 0 & 2 & 11 \\
\hline Non-synonymous coding & 30 & 8 & 42 & 28 & 5 & 5 & 10 & 11 & 10 & 34 & 183 \\
\hline Splice site & 3 & 3 & 3 & 0 & 0 & 1 & 1 & 0 & 2 & 0 & 13 \\
\hline Synonymous coding & 24 & 1 & 54 & 13 & 6 & 2 & 10 & 6 & 33 & 22 & 171 \\
\hline Intronic & 124 & 22 & 234 & 16 & 0 & 2 & 10 & 1 & 0 & 12 & 421 \\
\hline $5^{\prime}$ UTR & 12 & 2 & 40 & 3 & 1 & 0 & 4 & 0 & 1 & 8 & 71 \\
\hline 3' UTR & 43 & 0 & 55 & 10 & 1 & 26 & 1 & 13 & 27 & 12 & 188 \\
\hline Upstream & 1 & 0 & 3 & 1 & 6 & 1 & 1 & 0 & 4 & 6 & 23 \\
\hline Downstream & 5 & 0 & 5 & 0 & 3 & 1 & 1 & 0 & 2 & 8 & 25 \\
\hline Other* & 1 & 0 & 0 & 0 & 0 & 0 & 1 & 1 & 0 & 4 & 7 \\
\hline Total number of variants & 246 & 37 & 436 & 73 & 23 & 38 & 40 & 33 & 79 & 108 & 1113 \\
\hline
\end{tabular}

*Essential Splice Site (DDX58); Stop Gained (TLR3, TLR7, TLR10). The genetic variants described in the 1000 Genomes Project Pilot data are: Frameshift coding: structural mutation in the coding sequence, resulting in a frame shift of reading (A, B); Non-synonymous coding: nucleotide substitution in the coding sequence (A, B), resulting in an amino acid change in the peptide chain (A, C); Splice Site: 1-3bp into an exon or 3-8bp into an intron (A); Synonymous coding: nucleotide substitution in the coding sequence $(A, B)$, but not resulting in an amino acid change (C); Intronic: mutation in intron (A); 5'UTR: in $5^{\prime}$ untranslated region (A, B); $3^{\prime} U T R$ : in $3^{\prime}$ untranslated region (A, B); Upstream: mutation within $5 \mathrm{~kb}$ upstream of the $5^{\prime}$ end of transcript $(A)$; Downstream: mutation within $5 \mathrm{~kb}$ downstream of the $3^{\prime}$ end of transcript $(A)$.

severe manifestation of the influenza infection, since the possibility of heterozygosity enhances when $\mathrm{C}$ and $\mathrm{T}$ allelic frequencies are similar. The Japanese population (JPT, C=97.8-4.3\% C/T genotype) had the highest frequency of the $\mathrm{C}$ allele detected in the 1000 Genomes Project database, indicating that possibly only $4.3 \%$ of the population might be susceptible to acute pneumonia associated with IAV infection.

Four single nucleotide polymorphisms (SNPs) that showed association with severe illness were identified in a case-control association study on 91 patients with confirmed H1N1 infection-induced pneumonia (Mänz et al., 2013). The first SNP was located in the genetic locus for the Replication Protein A Interacting Protein (RPAIN). RPAIN facilitates the nuclear localization of RPA, a key protein in maintaining DNA integrity and homeostasis. The second SNP was found in the Complement component 1 gene coding for a subcomponent binding protein (C1QBP) gene. C1QBP inhibits the complement activation. The third SNP was found within the gene encoding the CD32 (also called FCGR2A). The CD32 is a cell surface receptor with low affinity for $\operatorname{IgG}$, it is found on phagocytic cells such as macrophages and neutrophiles that are involved in the process of phagocytosis and clearing of immune complexes. The last SNP was located within the potentially intergenic region of chromosome 3. Since two of these SNPs are associated with the genes whose products take part in either the clearing of immune complexes (FCGR2A), or in complement activation (C1QBP), it is reasonable to hypothesize that the severe disease outcome of H1N1 infection may result from variation in the host's immune response.

A new study reports a direct association between polymorphisms of rs17561 in the IL1A gene and rs1143627 in the IL1B gene and higher susceptibility to $\mathrm{A}(\mathrm{H} 1 \mathrm{~N} 1)$ infection (Liu et al., 2013). Interleukins IL1A and IL1B are very important in influenza infection, as both induce the expression of a variety of inflammatory mediators that may initiate the cascade of inflammatory responses and activation of $\mathrm{T}$ cells (Acosta-Rodriguez et al., 2007). IL1B has been demonstrated to mediate acute pulmonary inflammation, which is one of the main causes of death related to influenza A virus, while IL1A secretion is regulated by the NLRP3 inflammasome (Schmitz et al., 2005; Dawood et al., 2012; Gross et al., 2012). The rs17561T variant in the IL1A gene is present in low frequencies in the 1000 Genomes Project samples. The frequency of this allele ranges from $6 \%$ (in Southern Han Chinese) to a maximum of $35 \%$ (in British samples). The European samples (Iberian, British, Europeans residents in Utah, Toscani and Finnish) showed the highest frequencies of the $\mathrm{T}$ allele associated with the higher susceptibility to H1N1 influenza A infection. The SNP rs1143627C in the IL1B gene is very frequent in all populations in the 1000 Genomes Project, but in particular among Mexicans, Puerto Ricans, Luthya from Kenya, and Yoruba from Nigeria, ranging from 52\% in Mexicans to $75 \%$ in Luhya. In other populations, the frequencies range from $21 \%$ (in Iberians), to $48 \%$ (in Americans of African descent). If such SNPs strongly influence susceptibility to influenza $\mathrm{A}$ infection, the high frequencies might explain rapid spread and the acute respiratory inflammation among human populations.

The mechanisms of RNA sensing and pattern recognition are very important in the first phase of infection. Mutations in the genes that encode pattern-recognizing proteins could prevent a successful recognition of pathogen patterns. It is striking that a low number of mutations in these genes is observed, as shown in Table 3. Most of the variation is located in intronic regions, which may be neutral to the function of the expressed products. This is not true for the TLR genes, where both non-synonymous and synonymous modifications are predominantly in coding regions, which may probably reflect evolutionary increase in the types of patterns recognized.

\section{INFECTION SPREAD: ADAPTIVE IMMUNE RESPONSE TO INFLUENZA VIRUS}

The adaptive phase of the immune response to influenza virus is crucial for the effective fight against infec- 


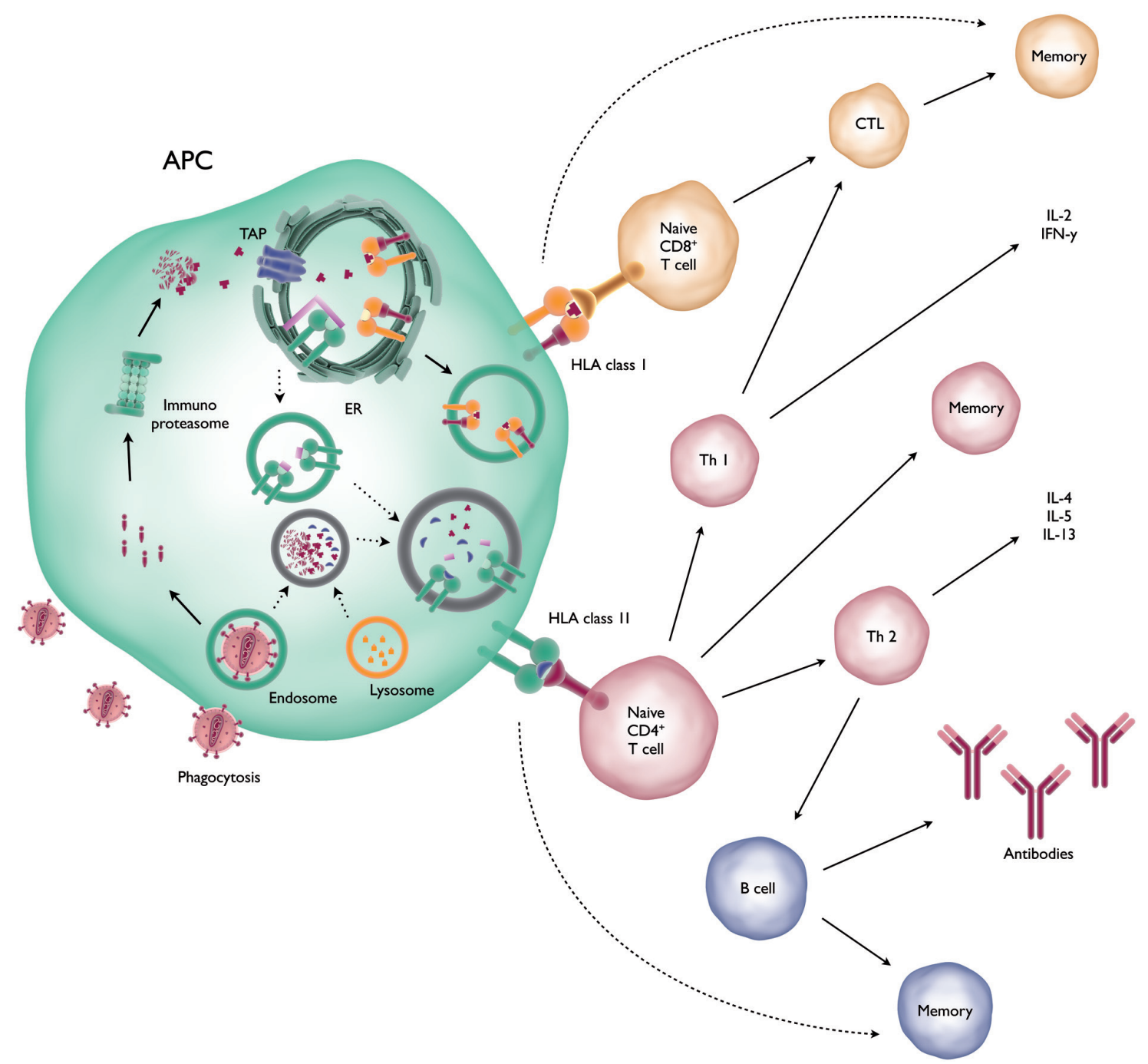

Figure 3. HLA antigen presentation pathways and activation of the adaptive immune response.

Both HLA class I and HLA class II presentation pathways are activated during influenza virus infections. HLA class I presentation (solid arrows): the epitopes obtained by immunoproteasome degradation of cytosol proteins, are transported in the ER via TAP. The HLA class I epitope complexes are then transported to the plasma membrane where they stimulate the differentiation of cytotoxic CD8+ T cell (CTL) and provide signaling for the suppression of the infected cells by CTL effector (adaptive cellular response). HLA class II presentation (dotted arrows): the epitopes obtained from the proteolytic degradation within endosomal compartments are then assembled with HLA class II proteins. The HLA class II - epitope complexes are transported to the plasma membrane where they both stimulate the differentiation of T-helper CD4+ and activate T-helper effectors triggering the humoral response. Induction of immune responses after a primary influenza $A$ virus infection is indicated by solid arrows. Virus-specific memory cell populations upon secondary encounter with an influenza $A$ virus are indicated by dashed arrows.

tion, and can be divided into humoral and cellular immune response (Fig. 3). The humoral immune response is characterized by the degradation of viral proteins into peptides, further shown on the cell surface of antigenpresenting cells (APC) in complex with human leucocyte antigen (HLA) class-II proteins. The HLA class-IIepitope complexes interact with CD4+ T-cells, which in turn trigger the production of virus-specific antibodies. In contrast to the humoral response, the cellular immune response results in the activation of naïve CD8+ $\mathrm{T}$ cells and their differentiation into cytotoxic $\mathrm{T}$ lymphocytes (CTLs). Immunoproteasomes present in the host cell cytosol degrade viral proteins into peptides that are then transported to the endoplasmic reticulum (ER) via TAP (transporter of antigen processing), where they are loaded onto HLA class-I molecules. HLA class-I-epitope complexes are then transported via the Golgi to the cell membrane, where they can be recognized by virusspecific CTLs (Guermonprez et al., 2002). The CTLs are able to kill the infected cells, thus limiting the spread of the virus.

\section{Humoral immune response to influenza virus}

Elderly people exposed to influenza A/H1N1 virus in the 1950 s were relatively spared from infection during the 2009 pandemic strain, since they have developed cross-reactive antibodies (Yu et al., 2008; Hancock et al., 2009). This observation suggests that the humoral immune system triggers long-lasting antibody-mediated protection against influenza strains that resemble the original strain of infection. In the humoral adaptive phase of the immune response, B-cells are stimulated by the production of influenza-virus-specific antibodies primarily directed against HA, NA and M2 viral proteins (Baum- 
garth et al., 2000; Waffarn \& Baumgarth, 2011). Antibodies directed against the trimeric globular HA head efficiently block receptor-mediated endocytosis of the virus (De Jong et al., 2003). However, most of antibodies are strain-specific and fail to neutralize other influenza serotypes (Yu et al., 2008).

Neuraminidase (NA) is a viral glycoside hydrolase which, catalyzing the hydrolysis of terminal sialic acid residues from both newly formed virions and host cell receptors, facilitates the release and spread of the newly formed viral particles (von Itzstein, 2007). Anti-NA antibodies inhibit the enzymatic activity of NA thereby limiting viral spread and shorten severity and duration of illness (Bosch et al., 2010; Kilbourne et al., 2009). NAspecific antibodies may also contribute to the clearance of virus-infected cells by facilitating Antibody-Dependent Cell-Mediated Cytotoxicity (ADCC) (Carolien et al., 2012). Tetrameric transmembrane viral protein M2 has ion channel activity and plays an important role in unpacking the virus in the endosome (Schnell \& Chou, 2008). The protective effect of cross-reactive anti-M2 antibodies was first demonstrated in mice after passive transfer of M2-specific monoclonal antibodies (Kim et al., 2013), and is attributed to ADCC activation (Mozdzanowska et al., 1999; El Bakkouri et al., 2011). The heterosubtypic protective effect of M2-specific antibodies most probably stems from strong conservation of M2 protein sequence among different influenza virus strains (Tompkins et al., 2007; Fiers et al., 2009; Fu et al., 2009; Schotsaert et al., 2009; Wang et al., 2009; Ebrahini \& Tebianian, 2011).

The humoral response induces the production of antibodies targeting other viral proteins, including the highly conserved NP protein (Carragher et al., 2008). Although NP-specific antibodies are non-neutralizing to viruses, there is some evidence that they contribute to establishing protective immunity (Lamere et al., 2011; Carragher et al., 2008). Their mode of action may include ADCC of infected cells and opsonisation of NP, resulting in improved T-cell responses (Bodewes et al., 2010; Sambhara et al., 2001). However, the protective effect of non HA/ NA antibodies is still under debate.

The $\operatorname{IgA}$, IgG and $\operatorname{IgM}$ antibody isotypes are induced upon primary influenza virus infection, whereas IgM responses are not observed after secondary infection (Carolien et al., 2012). Virus-specific serum $\operatorname{IgA}$ responses seem indicative for recent infection with influenza virus (Voeten et al., 1998; Koutsonanos et al., 2011), while virus-specific IgG antibodies correlate with long-lasting protection, whereby these antibodies match the strains causing the infection (Koutsonanos et al., 2011; Onodera et al., 2012). IgM antibodies can neutralize the virus but also activate the complement system (Jayasekera et al., 2007; Fernandez Gonzalez et al., 2008). In addition to serum antibodies, influenza virus infection also induces local mucosal secretory IgA antibody responses aimed at protecting airway epithelial cells from infection (Onodera et al., 2012).

\section{Cellular immune response to influenza virus $-\mathrm{T}$ Cells CD4+}

Activation of CD4+ $\mathrm{T}$ cells occurs upon recognition of viral epitopes associated with MHC class-II molecules and interaction with co-stimulatory molecules on APCs. Naïve CD4+ T cells can differentiate into CD4+ Th1 cells or Th2 cells (Fig. 3). Th1 cells are mainly involved in regulation of the CTL response (Zhu \& Paul, 2010a), and in the induction of memory CD8+ T cells
(Riberdy et al., 2000; Belz et al., 2002; Deliyannis et al., 2002). Th2 cells promote the activation and differentiation of B-cells, resulting in antibody production (Zhu \& Paul, 2010b; Okoye \& Wilson, 2011). Two different processes, namely antibody class-switching and somatic hypermutation determine the affinity maturation of the influenza-specific antibodies, drastically empowering their efficiency (Kamperschroer et al. 2006). Memory CD4+ T cells, induced after a primary influenza A virus infection, contribute to a faster control of subsequent influenza A virus infections (Strutt et al., 2010). Lung resident memory CD4+ T cells in particular play an important role in protection against secondary influenza $\mathrm{A}$ infection.

\section{Cellular immune response to influenza virus $-\mathrm{T}$ Cell CD8+}

The activation of $\mathrm{CD} 8+\mathrm{T}$ cells occurs upon recognition of viral epitopes associated with MHC class-I molecules on APCs in the draining lymph nodes. This process leads to the differentiation of CD8+ $\mathrm{T}$ into cytotoxic T lymphocytes (CTLs), which migrate to the site of infection in order to recognize and eliminate the host cells infected by the influenza virus, thereby preventing the production and spread of a progeny virus (Nakanishi et al., 2009). The interaction of T-cell receptor (TCR) with the HLA class-I-epitope complex stimulates CTLs to release perforin and granzymes, causing the apoptosis of infected cells (Andrade, 2010; Moffat et al., 2009). Proinflammatory cytokines like TNF-alpha, which inhibit virus replication and enhance lytic activity (La Gruta et al., 2004; La Gruta et al., 2007; Metkar et al., 2008; Andrade, 2010; van Domselaar \& Bovenschen, 2011), are also produced. After infection, the formation of a pool of memory CD8+ $\mathrm{T}$ cells occurs, constituting the basis for strong and fast recall responses upon secondary infections (Zimmermann et al., 1999; Chang et al., 2007; Hikono et al., 2007; DiSpirito \& Shen, 2010; van Gisbergen et al., 2011). Virus-specific CTLs are mainly directed against epitopes present within highly conserved viral proteins, such as NP, M1 and PA. This implies an efficient cross-reactivity that allows the CTLs to attack cells infected by different influenza A subtypes (Assarssen et al., 2008; Kreijtz et al., 2008; Lee et al., 2008). Studies on mice confirmed this hypothesis, showing that CD8+ T cells contribute to both homo- and heterosubtypic immunity (Kreijtz et al., 2007; Grebe et al., 2008; Kreijtz et al., 2009; Hillaire et al., 2011a; Hillaire et al., 2011b).

However, the evidence of CTL-induced immune protection against influenza in human is still very limited. The presence of heterosubtypic memory CD4+ and CD8+ T cells against the 2009 pandemic H1N1 virus was detected in naïve individuals (Sridhar et al., 2012). More circumstantial evidence for a protective role for $\mathrm{CD} 8+\mathrm{T}$ cells in heterosubtypic influenza infections stems from epidemiological studies. People who had a symptomatic influenza A infection with the H1N1 strain prior to the 1957 pandemic were partially protected from infection with the pandemic H2N2 strain. A similar trend was found in isolated infections with the H5N1 (Carolien et al., 2012).

\section{Genetic variability in the adaptive immune response}

The genetic variability of HLA genetic loci is known to be very large in any given population (c.f. Table 3). HLA hyper-variability is in fact the basic mechanism used by the host to ensure the recognition of potentially dangerous non-self molecules, triggering activation of the adaptive immune response against these molecules ( $\mathrm{Ta}$ - 
Table 4A. Genetic variability within the three principal genetic loci of classic HLA class-I genes (the data retrieved from the $1000 \mathrm{Ge}-$ nomes Project database)

\begin{tabular}{llccc}
\hline Type of variant & HLA-A & HLA-B & HLA-C & SUM \\
\hline Essential splice site & 34 & 10 & 12 & 56 \\
\hline Stop Gained & 71 & 26 & 23 & 120 \\
\hline Frameshift coding & 577 & 127 & 94 & 798 \\
\hline Non-synonymous coding & 1232 & 382 & 857 & 2471 \\
\hline Splice site & 206 & 28 & 48 & 282 \\
\hline Synonymous coding & 486 & 148 & 973 \\
\hline Intronic & 1519 & 557 & 339 & 3306 \\
\hline 5' UTR & 74 & 28 & 1230 & 110 \\
\hline 3' UTR & 909 & 191 & 8 & 1368 \\
\hline Upstream & 60 & 14 & 268 & 108 \\
\hline Downstream & 70 & 60 & 34 & 189 \\
\hline Total number of variants & 5133 & 1535 & 59 & 9605 \\
\hline
\end{tabular}

See the legend of Table 1 for explanations

Table 4B. Genetic variability of HLA class II $\beta$-chains within the three principal genetic loci (the data retrieved from the $1000 \mathrm{Ge}$ nomes Project database)

\begin{tabular}{|c|c|c|c|c|c|c|c|}
\hline Type of variant & HLA-DPB1 & HLA-DQB1 & HLA-DQB2 & HLA-DRB1 & HLA-DRB3 & HLA-DRB5 & SUM \\
\hline Essential splice site & 2 & 27 & 0 & 2 & 3 & 5 & 39 \\
\hline Stop Gained & 12 & 42 & 0 & 4 & 1 & 11 & 70 \\
\hline Frameshift coding & 0 & 150 & 0 & 35 & 3 & 24 & 212 \\
\hline Non-synonymous coding & 176 & 1071 & 18 & 166 & 89 & 150 & 1670 \\
\hline Splice site & 10 & 138 & 4 & 9 & 2 & 2 & 165 \\
\hline Synonymous coding & 69 & 491 & 33 & 90 & 38 & 62 & 783 \\
\hline Intronic & 192 & 3099 & 181 & 267 & 142 & 191 & 4072 \\
\hline 5' UTR & 3 & 60 & 1 & 16 & 13 & 4 & 97 \\
\hline 3' UTR & 117 & 633 & 48 & 113 & 86 & 130 & 1127 \\
\hline Upstream & 7 & 100 & 3 & 20 & 15 & 11 & 156 \\
\hline Downstream & 9 & 141 & 4 & 28 & 17 & 6 & 205 \\
\hline Total number of variants & 597 & 5883 & 292 & 744 & 405 & 580 & 8501 \\
\hline
\end{tabular}

See the legend of Table 1 for explanations.

bles $4 \mathrm{~A}$ and $4 \mathrm{~B}$ ). The recognition of the HLA-epitope complexes by $\mathrm{T}$ cell receptor (TCR) is crucial for activation of the adaptive immune response. With this degree of genetic variability, it is extremely difficult to associate single HLA mutations with a differential response to influenza virus infection. Usually entire HLA alleles or specific allele combinations are considered, as they are more likely to be associated with specific phenotypic effects. Mutations in these regions could either prevent the formation of HLA-epitope complexes (Price et al., 2000; Voeten et al., 2000; Berkhoff et al., 2004; Rimmelzwaan et al., 2004; Berkhoff et al., 2007a) or cause the epitope to escape recognition by TCR, since the epitope no longer matches the specificity of the TCR (Price et al., 2000; Boon et al., 2002; Berkhoff et al., 2007a; Berkhoff et al., 2007b).

Mutations within viral epitopes were shown to have a direct effect on the efficiency of CTL response (Carolien et al., 2012). These types of mutations have been observed in escape mutants of viruses that chronically infect their host, like HIV-1 (Huet et al., 1990; Cale et al., 2011). Substitutions of epitopes recognized by CTL have also been observed during the evolution of seasonal A/ H3N2 influenza viruses (Voeten et al., 2000; Rimmelzwaan et al., 2004; Berkhoff et al., 2007a). The R384G substitution in the HLA-B*2705-restricted NP383-391 epitope (Voeten et al., 2000) considerably affects the human virus-specific CTL response in vitro (Berkhoff et al., 2007a) while the HLA-B*3501 restricted NP418-426 epitope (Boon et al., 2002; Berkhoff et al., 2007b) displays signs of antigenic drift (Boon et al., 2004), explaining the cross-reactivity of CTL against contemporary viruses with historic strains (Gras et al., 2010). The variation rate of CTL epitopes could be considerably functionally constrained. For instance, the M1 58-66 epitope is highly conserved despite its immunodominant nature, probably because mutations within this epitope compromise the virus fitness (Berkhoff et al., 2006). 
It is noteworthy that the most variable of the nonHLA genes (NLRP3, with 496 variants) are still less variable, according to the data from the 1000-genomes Project, than the average for the nine HLA genes shown here. The most conserved gene in the HLA system, HLA-DQB2, has 292 described variants. The HLA-B gene, on the other hand, has 1,535 variants, which is still lower than that recorded by the IPD-TGTM/HLA website, which as (of May 2014) identifies 3,455 alleles, encoding 2,577 different proteins. Such enormous quantity of variants, underscores the importance of their function, since they should attach and present a plethora of possible peptides to cytotoxic and memory lymphocytes. The more universal are the HLA molecules, the more efficient will be the peptide presentation and the activity of the adaptive immune system.

\section{CONCLUDING REMARKS}

\section{It is more important to know what sort of person has a disease, than to know what sort of disease a person has}

Hippocrates of Cos (c. 460 BC - c. 370 BC)

The initial motivation for this review was the work of Horby et al. (2012), that was concluded with an open question: Is susceptibility to severe influenza in bumans beritable? - hard to answer, but not due to a lack of genotyping or analytic tools, nor because of insufficient evidence from severe influenza cases, but because of the absence of a coordinated effort to define and assemble cohorts of cases. Here we presented an update overview of the host variability of genes associated with flu infection, and discuss the possible influence of this variability on the severity of flu infection. Each virus-host interaction begins with entry of the virus into the host organism, and ends either in death of the individual or in elimination of the virus by the immune system. Evolution of the host-pathogen interactions yields variants in host genes, several of which are ultimately associated with bad or good prognosis following infection, while boosting the host's future resilience towards given, specific strain subtype of the viral epitopes. Even if the severity of infection was mild and/or asymptomatic, these variants have been shown to be polymorphic in different human populations, which could be correlated with the different rates of morbidity/mortality from the influenza A infectivity. Therefore, the answer to the Horby et al. (2012) question is positive, the susceptibility to severe influenza in humans is heritable.

On the other hand, it does not mean that all causes and variance in symptomatology and morbidity of flu infections have been discovered, or that they are only due to host genetic profile, but there are clearly several genes in the human genome that might have a direct impact on the course of influenza A infections. In particular, when considering the ethnicity-derived genomic variance, some aspects of specific habitats and climates should not be neglected. In temperate regions the peak flu infectivity is felt predominantly during the winter months and epidemics recur with a highly predictable seasonal pattern. The studies using mouse-adapted strains of influenza virus, with experiments performed in the winter months yielded a transmission rate of $58.2 \%$, yet of only $34.1 \%$ in summer (Schulman \& Kilbourne, 1963). It has been hypothesized that possible causes of such seasonality include fluctuations in host immune efficiency mediated by seasonal factors such as melatonin (Dowell, 2001) and vitamin D (Cannell et al., 2006) levels; the changes in host behavior (school attendance, indoor crowding, air travel, etc.); but in particular environmental factors, including temperature (Eccles, 2002), relative humidity, and the direction of seasonal winds movement in the upper atmosphere (Hammond et al., 1989). The role of the South-East Asia region, in particular in countries spanning latitudes from subtropical at the south to high-mountainous at the north through several climactic zones, as spawning grounds of new flu strains is very well known (see e.g. Le et al., 2013), and a field of intense phylogeographical research (Wallace \& Fitch, 2008 , for a review). In contrast, the situation differs in the [sub]tropical regions, which experience influenza throughout the year, with somewhat increased incidence during rainy seasons (Viboud et al., 2006, Shek \& Lee, 2003). Such regions, like rainforests of equatorial Africa, or Amazonian regions of Brazil, Venezuela and Ecuador, are still potentially rich areas for a the concerted efforts to connect the possible ethnic genomics factors in isolated communities, with the influenza A prevalence and infectivity patterns.

Also, many factors can cause modifications in DNA (epigenetic modifications) that alter the gene expression. Several studies support the theory of prenatal/childhood programming as the origin of various adult diseases (Nicoletto \& Rinaldi, 2011, Ahmed, 2010). Epigenetic modifications were described to explain adult disease in response to environmental modifications in prenatal or childhood. For example, Yang and Huffman (2013) showed that individuals who suffer some sort of nutritional privation during gestation tend to become obese adults. It can be thought that if the pattern of methylation that is programmed in one's genome during development can affect the way that individual will react to a diet as an adult, it might possibly affect the way immune-related genes are expressed during the infections (Guoying W et al., 2013).

Very recently the work of Guihot and coworkers (2014) demonstrated some curious cases that impose more questions than answers. The authors have found biological markers that can predict whether an individual is more prone to suffer lethal consequences to influenza infection. However, the genetic variability that underlies such markers is not well understood - e.g., some of the markers indicated a "trapping" antibodies in the lungs for the lethal cases, whilst the survivors had the antibodies freed into a blood. In another recent study Worobey and coworkers (2014) have hypothesized that the high mortality during the 1918 Spanish flu pandemic among adults aged $\sim 20$ to $\sim 40$ years might have been primarily due to their childhood exposure to a heterosubtypic putative $\mathrm{H} 3 \mathrm{~N} 8$ virus - estimated as to have been circulating from $\sim 1889-1900$. All other age groups (except immunologically naïve infants) were likely to be partially protected by childhood exposure to N1 and/or H1related antigens. Such tenet poses immediate questions. What possible immunological mechanism[s] already described might explain such an increase of mortality rates? Especially a mechanism of contrasting the $\mathrm{H} 3$ non-naïve young-adult Spanish flu victims (but putatively naïve towards H1 serotype), with infants - by definition naïve to all HA subtypes. In effect such a mechanism would require a convincingly plausible pathway[s] of suppressing immunity specifically by an action of $\mathrm{H} 3$-derived epitopes. One possible mechanism would be that the exposure to this putative $\mathrm{H} 3 \mathrm{~N} 8$ virus could have caused a methylation pattern in some genes, especially on some paths of imune response, and as consequence these patients had an extremely severe flu. Also, maybe not all individuals exposed to this virus developed the same 
methylation patterns and final supressions due to the genetic variability known to exist in human populations. The authors postulate that a mechanism akin to original antigenic sin (OAS, Francis T, 1960) may have interfered with immune responses in some of those infected in 1918, and peaked in those exposed previously to the 1889 virus. However, such hypothesis opens important questions about possible molecular and immunological mechanisms pertaining to the actual OAS phenomena "in action". It is obvious that many more studies of this type will be necessary to better understand how the environment and host genetic variability affects the susceptibility to the influenza A virus. The present review shows that both host genetic variability as well as environment are clearly factors of great importance to determine such susceptibility.

\section{Conflicts of interests}

Authors declare no conflict of interests.

\section{Acknowledgements}

We are grateful to Anna Lisa Lucido (Jackson Laboratory for Genomic Medicine) for her critical review of the manuscript.

This work was supported by the Polish Ministry of Education and Science (grant number NCN 2013/09/B/ NZ2/00121). GM was financed by research fellowship within Project "Information technologies: Research and their interdisciplinary applications". ACA was supported by a doctoral fellowship granted by Coordenação de Aperfeiçoamento Pessoal de Nível Superior, CAPES., Brazil. SFO received a fellowship from CNPq (Conselho Nacional de Desenvolvimento Científico), Brazil. Additional partial funding was generously provided by the WND-POIG.01.01.02-00-007/08 grant from the European Regional Development Fund.

\section{REFERENCES}

1000 Genomes Pilot Browser - pilotbrowser.1000genomes.org/index. html (as of May 2014).

Abbas YM, Pichlmair A, Górna MW, Superti-Furga G, Nagar B (2013) Structural basis for viral 5'-PPP-RNA recognition by human IFIT proteins. Nature 494: 60-64.

Acosta-Rodriguez EV, Napolitani G, Lanzavecchia A, Sallusto F (2007) Interleukins 1 beta and 6 but not transforming growth factor-beta are essential for the differentiation of interleukin 17-producing human T helper cells. Nat Immunol 8: 942-949.

Ahmed F (2010) Epigenetics: Tales of adversity Nature 468: S20; doi:10.1038/468S20a.

Allen IC, Scull MA, Moore CB, Holl EK, McElvania-TeKippe E, Taxman DJ, Guthrie EH, Pickles RJ, Ting JPY (2009) The NLRP3 inflammasome mediates in vivo innate immunity to influenza A virus through recognition of viral RNA. Immunity 30: 556-565.

Andrade F (2010) Non-cytotoxic antiviral activities of granzymes in the context of the immune antiviral state. Immunol Rev 235: 128-146.

Andrewes CH (1939) Immunity in influenza: the bearing of recent research work: (section of epidemiology and state medicine). Proc $\mathrm{R}$ Soc Med 32: 145-152.

Assarsson E, Bui HH, Sidney J, Zhang Q, Glenn J, Oseroff C, Mbawuike IN, Alexander J, Newman MJ, Grey H, et al. (2008) Immunomic analysis of the repertoire of T-cell specificities for influenza A virus in humans. J Virol 82: 12241-12251.

Bateman AC, Busch MG, Karasin AI, Bovin N, Olsen CW (2008) Amino acid 226 in the hemagglutinin of H4N6 influenza virus determines binding affinity for $\alpha 2,6$-linked sialic acid and infectivity levels in primary swine and human respiratory epithelial cells. $J V i$ rol 82: 8204-8209.

Baumgarth N, Herman OC, Jager GC, Brown L E, Herzenberg LA, Chen J (2000) B-1 and B-2 cell-derived immunoglobulin M antibodies are non redundant components of the protective response to influenza virus infection. J Exp Med 192: 271-280.

Belz GT, Wodarz D, Diaz G, Nowak MA, Doherty PC (2002) Compromised influenza virus-specific CD8(+)-T-cell memory in CD4(+)-T-cell-deficient mice. J Virol 76: 12388-12393.
Berkhoff EG, de Wit E, Geelhoed-Mieras MM, Boon AC, Symons J, Fouchier RA, Osterhaus AD, Rimmelzwaan GF (2006) Fitness costs limit escape from cytotoxic T lymphocytes by influenza A viruses. Vaccine 24: 6594-6596.

Berkhoff EG, Boon AC, Nieuwkoop NJ, Fouchier RA, Sintnicolaas K, Osterhaus AD, Rimmelzwaan GF (2004) A mutation in the HLAB*2705-restricted NP383-391 epitope affects the human influenza A virus-specific cytotoxic T-lymphocyte response in vitro. J Virol 78: $5216-5222$.

Berkhoff EG, Geelhoed-Mieras MM, Fouchier RA, Osterhaus AD, Rimmelzwaan GF (2007a) Assessment of the extent of variation in influenza A virus cytotoxic T-lymphocyte epitopes by using virusspecific CD8+ T-cell clones. J Gen Virol 88: 530-53566.

Berkhoff EG, Geelhoed-Mieras MM, Verschuren EJ, van Baalen CA, Gruters RA, Fouchier RA, Osterhaus AD, Rimmelzwaan GF (2007b) The loss of immunodominant epitopes affects interferongamma production and lytic activity of the human influenza virusspecific cytotoxic T lymphocyte response in vitro. Clin Exp Immunol 148: 296-306.

Bodewes R, Osterhaus AD, Rimmelzwaan GF (2010) Targets for the induction of protective immunity against influenza $\mathrm{A}$ viruses. $\mathrm{Vi}$ ruses 2: 166-188.

Boon AC, de Mutsert G, Graus YM, Fouchier RA, Sintnicolaas K, Osterhaus AD, Rimmelzwaan GF (2002) Sequence variation in a newly identified HLA-B35-restricted epitope in the influenza A virus nucleoprotein associated with escape from cytotoxic T lymphocytes. $J$ Virol 76: 2567-2572.

Boon AC, de Mutsert G, van Baarle D, Smith DJ, Lapedes AS, Fouchier RA, Sintnicolaas K, Osterhaus AD, Rimmelzwaan GF (2004) Recognition of homo- and heterosubtypic variants of influenza A viruses by human CD8+ T lymphocytes. I Immunol 172: 2453-2460.

Bosch BJ, Bodewes R, de Vries RP, Kreijtz JH, Bartelink W, van Amerongen G, Rimmelzwaan GF, de Haan CA, Osterhaus AD, Rottier PJ (2010) Recombinant soluble, multimeric HA and NA exhibit distinctive types of protection against pandemic swine-origin 2009 $\mathrm{A}(\mathrm{H} 1 \mathrm{~N} 1)$ influenza virus infection in ferrets. I Virol 84: 1036610374.

Brown DM, Dilzer AM, Meents DL, Swain SL (2006) CD4 T cell-mediated protection from lethal influenza: Perforin and antibody-mediated mechanisms give a one-two punch. J Immunol 177: 2888-2898.

Cale EM, Bazick HS, Rianprakaisang TA, Alam SM, Letvin NL (2011) Mutations in a dominant Nef epitope of simian immunodeficiency virus diminish TCR-Epitope peptide affinity but not epitope peptide-MHC class I binding J Immunol 187: 3300-3313.

Cannell JJ, Vieth R, Umhau JC, Holick MF, Grant WB, et al (2006) Epidemic influenza and vitamin D. Epidemiol Infect 134:1129-1140.

Carette JE, Guimaraes CP, Varadarajan M, Park AS, Wuethrich I, Godarova A, Kotecki M, Cochran BH, Spooner E, Ploegh HL, Brummelkamp TR (2009) Haploid genetic screens in human cells identify host factors used by pathogens. Science 326: 1231-1235.

Carolien E van de Sandt, Joost H C M Kreijtz, Guus F Rimmelzwaan (2012) Evasion of Influenza A Viruses from Innate and Adaptive Immune Responses. Viruses 4: 1438-1476.

Carragher D M, Kaminski D A, Moquin A, Hartson L, Randall T D (2008) A novel role for non-neutralizing antibodies against nucleoprotein in facilitating resistance to influenza virus. I Immunol 181: 4168-4176.

Chandrasekaran A, Srinivasan A, Raman R, Viswanathan K, Raguram S, Tumpey TM, Sasisekharan V, Sasisekharan R (2008) Glycan topology determines human adaptation of avian H5N1 virus hemagglutinin. Nature Biotechnology 26: 107-113.

Chang JT, Palanivel VR, Kinjyo I, Schambach F, Intlekofer AM, Banerjee A, Longworth SA, Vinup KE, Mrass P, Oliaro J et al (2007) Asymmetric $\mathrm{T}$ lymphocyte division in the initiation of adaptive immune responses. Science 315: 1687-1691.

Clarke L, Zheng-Bradley X, Smith R, Kulesha E, Xiao C, Toneva I, Vaughan B, Preuss D, Leinonen R, Shumway M, Sherry S, Flicek P, The 1000 Genomes Project Consortium (2012) The 1000 Genomes Project: data management and community access. Nature Methods 9: $1-4$.

Cohen M, Varki A (2010) The Sialome - Far more than the sum of its parts. OMICS J Int Biol 14: 455-464.

Cohen M, Zhang XQ, Senaati HP, Chen HW, Varki NM, Schooley RT, Gagneux P (2013) Influenza A penetrates host mucus by cleaving sialic acids with neuraminidase. Virol J 10: 321.

Cone RA (2009) Barrier properties of mucus. Adv Drug Deliv Rev 61: 75-85.

Das SR, Hensley SE, David A, Schmidt L, Gibbs JS, Puigbò P, Ince WL, Bennik JR, Yewdell JW (2010) Fitness costs limit influenza A virus hemagglutinin glycosylation as an immune evasion strategy. PNAS Plus early edition: 1-6.

Dawood FS, Iuliano AD, Reed C, Meltzer MI, Shay DK, Cheng PY, Bandaranayake D, Breiman RF, Brooks WA, Buchy P, Feikin DR, Fowler KB, Gordon A, Hien NT, Horby P, Huang QS, Katz MA, Krishnan A, Lal R, Montgomery JM, Mфlbak K, Pebody R, Presanin AM, Razuri H, Steens A, Tinoco YO, Wallinga J, Vong S, Bre- 
see J, Widdowson MA (2012) Estimated global mortality associated with the first 12 months of 2009 pandemic influenza A H1N1 virus circulation: a modelling study. Lancet Infect Dis 12: 687-695.

De Jong J C, Palache A M, Beyer W E, Rimmelzwaan G F, Boon A C, Osterhaus A D (2003) Haemagglutination-inhibiting antibody to influenza virus. Dev Biologicals 115: 63-73.

de Wit E, Fouchier RAM (2008) Emerging influenza. J Clin Virol 4:1-6.

Deliyannis G, Jackson DC, Ede NJ, Zeng W, Hourdakis I, Sakabetis E, Brown LE (2002) Induction of long-term memory CD8(+) T cells for recall of viral clearing responses against influenza virus. $J$ Virol 76: 4212-4221.

DiSpirito JR, Shen H (2010) Quick to remember, slow to forget: Rapid recall responses of memory CD8+ T cells. Cell Res 20: 13-23.

Dowell SF (2001) Seasonal variation in host susceptibility and cycles of certain infectious diseases. Emerg Infect Dis 7: 369-374.

Duez JM, Sixt N, Péchinot A (2008) Influenza virus infection: don't forget the role of the mucociliary system! J Antimicrobial Chemotherapy 63: 421-422.

Eccles R (2002) An explanation for the seasonality of acute upper respiratory tract viral infections. Acta Otolaryngol 122: 183-191.

Ebrahimi S M, Tebianian M (2011) Influenza A viruses: Why focusing on M2e-based universal vaccines. Virus Genes 42: 1-8.

El Bakkouri K, Descamps F, de Filette M, Smet A, Festjens E, Birkett A, van Rooijen N, Verbeek S, Fiers W, Saelens X (2011) Universal vaccine based on ectodomain of matrix protein 2 of influenza $\mathrm{A}$ : Fc receptors and alveolar macrophages mediate protection. I Immunol 186: 1022-1031.

El Moussi A, Kacem ABH, Slim A (2014) Loss and gain of N-linked glycosylation sites in globular head and stem of HA found in A/ H3N2 flu fatal and severe cases during 2013 Tunisia flu seasonal survey. Virus Genes 48: 189-192.

Esposito S, Molteni CG, Giliani S, Mazza C, Scala A, Tagliaferri L, Pelucchi C, Fossali E, Plebani A, Principi N (2012) Toll-like receptor 3 gene polymorphisms and severity of pandemic A/H1N1/2009 influenza in otherwise healthy children. Virol J 9: 270.

Fernandez Gonzalez S, Jayasekera JP, Carroll MC (2008) Complement and natural antibody are required in the long-term memory response to influenza virus. Vaccine 26: I86-I93.

Fiers W, de Filette M, El Bakkouri K, Schepens B, Roose K, Schotsaert M, Birkett A, Saelens, X (2009) M2e-based universal influenza A vaccine. Vaccine 27: 6280-6283.

Fleischer B (1998) Mechanism of glycosylation in the Golgi Apparatus. The J of Histochem and Cytochem 31: 1033-1040.

Francis T (1960) On the doctrine of original antigenic sin. Proc. Am. Philos. Soc. 104: 572-578.

Fritz JH, Ferrero RL, Philpott DJ, Girardin SE (2006) Nod-like proteins in immunity, inflammation and disease. Nature Immun 7:125057.

Fu TM, Freed DC, Horton MS, Fan J, Citron MP, Joyce JG, Garsky VM, Casimiro DR, Zhao Q, Shiver JW, et al. (2009) Characterizations of four monoclonal antibodies against M2 protein ectodomain of influenza A virus. Virology 385: 218-226.

Gack MU (2014) Mechanisms of RIG-I-like receptor activation and manipulation by viral pathogens. J Virol 88: 5213-5216.

Gambaryan A, Tuzikov A, Pazynina G, Bovin N, Balish A, Klimov A (2006) Evolution of the receptor binding phenotyoe of influenza A (H5) viruses. Virology 344: 432-438.

Garcia-Sastre A (2004) Identification and characterization of viral antagonists of type I interferon in negative-strand RNA viruses. In Curr Top Microbiol Immunol 283: 249-280.

Gaunitz S, Liu J, Nilsson A, Karlsson N, Holgersson J (2014) Avian influenza $\mathrm{H} 5$ hemagglutinin binds with high avidity to sialic acid on different $O$-linked core structures on mucin-type fusion proteins. Glycoconj J 31: 145-159.

Glaser L, Conenello G, Paulson J, Palese P (2007) Effective replication of human influenza viruses in mice lacking a major $\alpha 2,6$ sialyltransferase. Virus Research 126: 9-18.

Gog JR, Rimmelzwaan GF, Osterhaus AD, Grenfell BT (2003) Population dynamics of rapid fixation in cytotoxic $T$ lymphocyte escape mutants of influenza A. Proc Natl Acad Sci U S A 100: 11143-11147.

Gras S, Kedzierski L, Valkenburg SA, Laurie K, Liu YC, Denholm JT, Richards MJ, Rimmelzwaan GF, Kelso A, Doherty PC, et al. (2010) Cross-reactive CD8+ T-cell immunity between the pandemic H1N1-2009 and H1N1-1918 influenza A viruses Proc Natl Acad Sci U S A 107: 12599-12604.

Grebe KM, Yewdell JW, Bennink JR (2008) Heterosubtypic immunity to influenza A virus: Where do we stand? Mirrob Infect 10: 1024 1029.

Gross O, Yazdi AS, Thomas CJ, Masin M, Heinz LX, Guarda G, Quadroni M, Drexler SK, Tschopp J (2012) Inflammasome activators induce interleukin-1alpha secretion via distinct pathways with differential requirement for the protease function of caspase-1. Immunity 36: 388-400.

Guan Y, Ranoa DRE, Jiang S, Mutha SK, Li X, Baudry J, Tapping RI (2010) Human TLRs 10 and 1 share common mechanisms of innate immune sensing but not signaling. J Immunol 184: 5094-5103.
Guarnaccia T, Carolan LA, Maurer-Stroh S, Lee RTC, Job E, Reading PC, Petrie S, McCaw JM, McVernon J, Hurt AC, Kelso A, Mosse J, Barr IG, Laurie KL (2013) Antigenic drift of the pandemic 2009 A(H1N1) influenza virus in a ferret model. PloS Pathog 9: e1003354.

Guermonprez P, Valladeau J, Zitvogel L, Thery C, Amigorena, S (2002) Antigen presentation and $T$ cell stimulation by dendritic cells. Annu Rev Immunol 20: 621-667.

Guihot, A et al (2014) Low titers of serum antibodies inhibiting hemagglutination predict fatal fulminant influenza A (H1N1) 2009 infection. American journal of respiratory and critical care medicine. 189: 1240-1249.

Guo Z, Chen LM, Zeng H, Gomez JA, Plowden J, Fujita T, Katz JM, Donis RO, Sambhara S (2007) NS1 protein of influenza A virus inhibits the function of intracytoplasmic pathogen sensor, RIG-I. $A m$ J Respir Cell Mol Biol 36: 263-269.

Guoying W, et al (2013) Epigenetics and Early Life Origins of Chronic Noncommunicable Diseases, Journal of Adolescent Health 52:S14 -S21.

Hale BG, Albrecht RA, Garcia-Sastre A (2010) Innate immune evasion strategies of influenza viruses. Future Microbiol 5: 23-41.

Hammond GW, Raddatz RL, Gelskey DE (1989) Impact of atmospheric dispersion and transport of viral aerosols on the epidemiology of influenza. Rev Infect Dis 11: 494-497.

Hancock K, Veguilla V, Lu X, Zhong W, Butler E N, Sun H, Liu F, Dong L, DeVos J R, Gargiullo P M, et al (2009) Cross-reactive antibody responses to the 2009 pandemic H1N1 influenza virus. New Engl J Med. 361: 1945-1952.

Harduin-Lepers A, Vallejo-Ruiz V, Krzewinski-Recchi MA, Samyn-Petit B, Julien S, Delannoy P (2001) The human sialyltransferase family. Biochimie 83: 727-737.

Harduin-Lepers A, Mollicone R, Delannoy P, Oriol R (2005) The animal sialyltransferases and sialyltransferase-related genes: a phylogenetic approach. Glycobiology 15: 805-817.

Hatta M, Gao P, Halfmann P, Kawaoka Y (2001) Molecular basis for high virulence of Hong Kong H5N1 influenza A viruses. Science 293: $1840-1842$.

Heil F, Hemmi H, Hochrein H, Ampenberger F, Kirschning C, Akira S, Lipford G, Wagner H, Bauer S (2004) Species-specific recognition of single-stranded RNA via Toll-like receptor 7 and 8 . Science 303: $1526-29$

Henn AD, Wu S, Qiu X, Ruda M, Strover M, Yang H, Liu Z, Welle SL, Holden-Wiltse J, Wu H, Zand MS (2013) High-resolution temporal response patterns to influenza vaccine reveal a distinct human plasma cell gene signature. Scientific Reports 3: 2327.

Hertz T, Oshansky CM, Roddam PL, DeVincenzo JP, Caniza MA, Jojic N, Mallal S, Phillips E, James I, Halloran ME, Thomas PG, Corey L (2013) HLA targeting efficiency correlates with human T-cell response magnitude and with mortality from influenza A infection. Proc Natl Acad Sci 110: 13492-1397.

Hikono H, Kohlmeier J E, Takamura S, Wittmer ST, Roberts AD, Woodland DL (2007) Activation phenotype, rather than central- or effector-memory phenotype, predicts the recall efficacy of memory CD8+ T cells. J Exp Med 204: 1625-1636.

Hillaire ML, van Trierum SE, Kreijtz JH, Bodewes R, Geelhoed-Mieras MM, Nieuwkoop NJ, Fouchier RA, Kuiken T, Osterhaus AD, Rimmelzwaan GF (2011a) Cross- protective immunity against influenza pH1N1 2009 viruses induced by seasonal influenza A (H3N2) virus is mediated by virus-specific T-cells. J Gen Virol 92: 2339-2349.

Hillaire ML, Osterhaus AD, Rimmelzwaan GF (2011b) Induction of virus-specific cytotoxic $\mathrm{T}$ lymphocytes as a basis for the development of broadly protective influenza vaccines. I Biomed Biotechnol 2011: 939860

Horby P, Nguyen NY, Dunstan SJ, Baillie JK (2012) The Role of Host Genetics in Susceptibility to Influenza: A Systematic Review. PLoS ONE 7(3):e33180; doi:10.1371/journal.pone.0033180.

Huet S, Nixon DF, Rothbard JB, Townsend A, Ellis SA, McMichael AJ (1990) Structural homologies between two HLA B27-restricted peptides suggest residues important for interaction with HLA B27. Int Immunol 2: 311-316.

Ichinohe T, Lee HK, Ogura Y, Flavell R, Iwasaki A (2009) Inflammasome recognition of influenza virus is essential for adaptive immune responses. I Exp Med 206:79-87.

IPD-IGTM/HLA statistics - http://www.ebi.ac.uk/ipd/imgt/hla/stats. html, accessed in May 7th, 2014.

Jayamaran A, Koh X, Li J, Raman R, Viswanathan K, Shriver Z, Sasisekharan R (2012) Glycosylation at Asn ${ }^{91}$ of H1N1 haemagglutinin affects binding to glycan receptors. Biochem J 444: 429435.

Jayasekera JP, Moseman EA, Carroll MC (2007) Natural antibody and complement mediate neutralization of influenza virus in the absence of prior immunity. J Virol 81: 3487-3494.

Jensen S, Thomsen AR (2012) Sensin of RNA viruses: a review of innate immune receptors involved in recognizing RNA virus invasion. J Virol 86: 2900-2910.

Kamperschroer C, Dibble JP, Meents DL, Schwartzberg PL, Swain SL (2006) SAP is required for Th cell function and for immunity to influenza. J Immunol 177: 5317-5327. 
Karlsson NG, Herrmann A, Karlsson H, Johansson MEV, Carlstedt I, Hansson GC (1997) The Glycosylation of rat intestinal Muc2 mucin varies between rat strains and the samll and large intestine: A study of $O$-linked oligossaccharides by a mass spectrometric approach. $J$ Biol Chem 272: 27025-27034.

Kato H, Takeuchi O, Sato S, Yoneyama M, Yamamoto M, Matsui K, Uematsu S, Jung A, Kawai T, Ishii KJ, Yamaguchi O, Otsu K, Tsujimura T, Koh CS, Sousa CR, Matsuura Y, Fujita T, Akira S (2006) Differential roles of MDA5 and RIG-I helicases in the recognition of RNA viruses. Nature 44: 101-105.

Kilbourne E.D, Pokorny B.A, Johansson B, Brett I, Milev Y, Matthews $\mathrm{J} T$ (2004) Protection of mice with recombinant influenza virus neuraminidase. J Infect Dis. 189: 459-461.

Kim HM, Lee YW, Lee KJ, Kim HS, Cho SW, van Rooijen N, Guan Y, Seo SH (2008) Alveolar macrophages are indispensable for controlling Influenza viruses in lungs of pigs. J Virol 82: 4265-4274.

Kim MC, Lee JS, Kwon YM, O E, Lee YJ, Choi JG, Wang BZ, Comans RW, Kang SM (2013) Multiple heterologous M2 extracellular domains presented on virus-like particles confer borader and stronger M2 immunity than live influenza A virus infection. Antiviral Res 99: 328-335.

Kirkham S, Sheenan JK, Knight D, Richardson PS, Thornton DJ (2002) Heterogeneity of airway mucus: variations in the amounts nad glycoforms of the major oligomeric mucins MUC5AC and MUC5B. Biochem J 361: 537-546.

Kitagawa H, Paulson JC (1994) Differential expression of five sialyltransferase genes in human tissues. The J of Biol Chem 269: 1787217878.

Knowles MR, Boucher RC (2012) Mucus clearance as a primary innate defense mechanism for mammalian airways. J Clin Invest 109: $571-577$.

Koel BF, Burke DF, Bestebroer TM, van der Vliet S, Zondang GCM, Vervaet G, Skepner E, Lewis NS, Spronken MIJ, Russell CA, Eropkin MY, Hurt AC, Barr IG, de Jong JC, Rimmelzwaan GF, Osterhaus ADME, Fouchier RAM, Smith DJ (2013) Substitutions near the receptor binding site determine major antigenic chance during influenza virus evolution. Science 342: 976-979.

Koutsonanos DG, del Pilar Martin M, Zarnitsyn VG, Jacob J, Prausnitz MR, Compans RW, Skountzou I (2011) Serological memory and long-term protection to novel H1N1 influenza virus after skin vaccination. I Infect Dis 204: 582-591.

Koyama S, Ishii KJ, Kumar H, Tanimoto T, Coban C, Uematsu S, Kawai T, Akira S (2007) Differential Role of TLR and RLR-signaling in the immune responses to influenza $A$ virus infection and vaccination. J Immunol 179: 4711-4720.

Kreijtz JHCM, Bodewes R, van Amerongen G, Kuiken T, Fouchier RAM, Osterhaus AD, Rimmelzwaan GF (2007) Primary influenza $A$ virus infection induces cross-protective immunity against a lethal infection with a heterosubtypic virus strain in mice. Vaccine 25: 612-620.

Kreijtz JHCM, de Mutsert G, van Baalen CA, Fouchier RAM, Osterhaus AD, Rimmelzwaan GF (2008) Cross-recognition of avian H5N1 influenza virus by human cytotoxic T-lymphocyte populations directed to human influenza A virus. J Virol 82: 5161-5166.

Kreijtz JHCM, Bodewes R, van den Brand JM, de Mutsert G, Baas C, van Amerongen G, Fouchier RAM, Osterhaus AD, Rimmelzwaan GF (2009) Infection of mice with a human influenza A/H3N2 virus induces protective immunity against lethal infection with influenza A/H5N1 virus. Vaccine 27: 4983-4989.

Kreijtz JHCM, Fouchier RAM, Rimmelzwaan GF (2011) Immune responses to influenza virus infection. Virus Res 162: 19-30.

La Gruta NL, Turner SJ, Doherty PC (2004) Hierarchies in cytokine expression profiles for acute and resolving influenza virus-specific CD8+ T cell responses: Correlation of cytokine profile and TCR avidity. J Immunol 172: 5553-5560.

La Gruta NL, Kedzierska K, Stambas J, Doherty PC. A question of self-preservation: Immunopathology in influenza virus infection. Immunol Cell Biol 85: 85-92.

Lamere MW, Moquin A, Lee FE, Misra RS, Blair PJ, Haynes L, Randall TD, Lund FE, Kaminski DA (2011) Regulation of antinucleoprotein IgG by systemic vaccination and its effect on influenza virus clearance. J Virol 85: 5027-5035.

Le Goffic R, Pothlichet J, Vitour D, Fujita T, Meurs E, Chignard M, Si-Tahar M (2007) Cutting edge: influenza A virus activates TLR3dependent inflammatory and RIG-I-dependent antiviral responses in human ling epithelial cells. J Immunol 178: 3368-3372.

Le MQ, Lam HM, Cuong VD, Lam TTY et al (2013). Migration and persistence of human influenza A viruses, Vietnam, 2001-2008. Emerging infectious diseases 19: 1756-1765.

Lee LY, Ha do LA, Simmons C, de Jong MD, Chau NV, Schumacher R, Peng YC, McMichael AJ, Farrar JJ, Smith GL, et al. (2008) Memory $\mathrm{T}$ cells established by seasonal human influenza $\mathrm{A}$ infection cross-react with avian influenza A (H5N1) in healthy individuals. J Clin Investig 118: 3478-3490.

Lee SMY, Kok KH, Jaume M, Cheung TKW, Yip TF, Lai JCC, Guan Y, Webster RG, Jin DY, Peiris JSM (2014) Toll like receptor 10 is involved in induction of innate immune responses to influenza virus infection. Proc Natl Acad Sci 111: 3793-3798.

Lewallen DM, Siler D, Iyer SS. (2009) Factors affecting protein-glycan specificity: Effect of spacers and incubation time. Chem Bio Chem 10: 1486-1489.

Lillehoj EP, Kim KC (2002) Airway mucus: its components and function. Arch Pharm Res 25: 770-780.

Lin TY \& Brass AL (2013) Host genetic determinants of influenza pathogenicity. Current Opinion in Virology 3: 531-536.

Lin KL, Suzuki Y, Nakano H, Ramsburg E, Gunn MD (2008) CCR2+ monocyte-derived dendritic cells and exudate macrophages produce influenza-induced pulmonary immune pathology and mortality. J Immunol 180: 2562-2572.

Liu Y, Li S, Zhang G, Nie G, Meng Z, Mao D, Chen C, Chen X, Zeng G (2013) Genetic variants in IL1A and IL1B contribute to the susceptibility to 2009 pandemic H1N1 influenza A virus. BMC Immunology 14: 37.

Lund E, Güttinger S, Calado A, Dahlberg JE, Kutay U (2004) Nuclear export of MicroRNA precursors. Science 303: 95-98.

Mänz B, Dornfeld D, Götz V, Zell R, Zimmermann P, Haller O, Kochs G, Schwemmle M (2013) Pandemic Influenza A viruses escape from restriction by human $\mathrm{MxA}$ through adaptive mutations in the nucleoprotein. PLOS Pathogens 9: e1003279.

Matrosovich M, Tuzikov A, Bovin N, Gambaryan A, Klimov A, Castrucci MR, Donatelli I, Kawaoka Y (2000) Early alterations of the receptor-binding properties of $\mathrm{H} 1, \mathrm{H} 2$ and $\mathrm{H} 3$ avian influenza virus hemagglutinins after their introduction into mammals. J Virol 74: 8502-8512.

Matrosovich M, Klenk HD (2003) Natural and synthetic sialic acidcontaining inhibitors of influenza virus receptor binding. Rev Med Virol 13: 85-97.

McKinstry KK, Strutt TM, Swain SL (2011) Hallmarks of CD4 T cell immunity against influenza. J Intern Med 269: 507-518.

Medof ME, Walter EI, Rutgers JL, Knowles DM, Nussenzweig V (1987) Identification of the complement decay-accelerating factor (DAF) on epithelium and glandular cells and in body fluids. $J$ Exp Med 165: 848-64.

Medzhitov R, Preston-Hurlburt P, Kopp E, Stadlen A, Chen C, Ghosh S, Janeway Jr CA (1998) MyD88 is an adaptor protein in the hToll/ IL-1 receptor family signaling pathways. Mol Cell 2: 253-258.

Metkar SS, Menaa C, Pardo J, Wang B, Wallich R, Freudenberg M, Kim S, Raja SM, Shi L, Simon MM et al. (2008) Human and mouse granzyme A induce a proinflammatory cytokine response. Immunity 29: $720-733$

Moffat JM, Gebhardt T, Doherty PC, Turner SJ, Mintern JD (2009) Granzyme A expression reveals distinct cytolytic CTL subsets following influenza A virus infection. Eur J Immunol 39: 1203-1210.

Mozdzanowska K, Maiese K, Furchner M, Gerhard W (1999) Treatment of influenza virus-infected SCID mice with nonneutralizing antibodies specific for the transmembrane proteins matrix 2 and neuraminidase reduces the pulmonary virus titer but fails to clear the infection. Virology 254: 138-146.

Münster AK, Eckhardt M, Potvin B, Mühlenhoff M, Stanley P, Gerardy-Schahn R (1998) Mammalian cytidine 5'-monophosphate $N$-acetylneuraminic acid sinthetase: A nuclear protein with evolutionarily conserved structural motifs. Proc Natl Acad Sci USA 95: 9140-9145.

Nadziejko C, Finkelstein I (1994) Inhibition of neutrophil elastase by mucus glycoprotein. Am J Respir Cell Mol Biol 11: 103-107.

Nakanishi Y, Lu B, Gerard C, Iwasaki A (2009) CD8(+) T lymphocyte mobilization to virus- infected tissue requires CD4(+) T-cell help. Nature 462: 510-513.

Ng BG, Buckingham KJ, Raymond K, Kircher M, Turner EH, He M, Smith JD, Eroshkin A, Szybowska M, Losfeld ME, Chong JX, Kozenko M, Li C, Patterson MC, Gilbert RD, Nickerson DA, Shendure J, Bamshad MJ, University of Washington Center for Mendelian Genomics, Freeze HH (2013) Mosaicism of the UDPGalactose Transporter SLC35A2 causes a Congenital Disorder of Glycosylation. The Amer J of Hum Genet 92: 632-636.

Nicholls JM, Bourne AJ, Chen H, Guan Y, Peiris JSM (2007) Sialic acid receptor detection in the human respiratory tract: evidence for widespread distribution of potential binding sites for human and avian influenza viruses. Respiratory Research 8: 73.

Nicholls JM, Lai J, Garcia JM (2012) Investigating the interaction between influenza And sialic acid: Making and breaking the link. In Influenza Virus Sialidase - A Drug Discovery Target. von Itzstein M ed.

Nicoletto SF, Rinaldi A (2011) In the womb's shadow. EMBO reports 12: $30-34$.

Ogasawara Y, Namai T, Yoshino F, Lee MC, Ishii K (2007) Sialic acid is an essential moiety of mucin as a hydroxyl radical scavenger. FEBS Letters 581: 2473-2477.

Ogura Y, Inohara N, Benito A, Chen FF, Yamaoka S, Nuñez G (2001) Nod2, a Nod1/Apaf-1 family member that is restricted to mono-

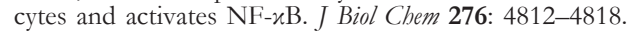


Ohuchi M, Ohuchi R, Feldmann A, Klenk HD (1997) Regulation of receptor binding affinity of influenza virus hemagglutinin by its carbohydrate moiety. J Virol 71: 8377-8384.

Okoye IS, Wilson MS (2011) CD4+ T helper 2 cells - Microbial triggers, differentiation requirements and effector functions. Immunology 134: 368-377.

Olczak M, Maszczak-Seneczko D, Sosicka P, Jakimowicz P, Olczak T (2013) UDP-Gal/UDP-GlcNAc chimeric transporter complements mutation defect in mammalian cells deficient in UDP-Gal transporter. Biochem And Biophys Res Commun 434: 473-478.

OMIM - Online Mendelian Inheritance in Men http://www.omim.org/ entry/314375 (accessed in 29/04/2014).

Onodera T, Takahashi Y, Yokoi Y, Ato M, Kodama Y, Hachimura S, Kurosaki T, Kobayashi K (2012) Memory B cells in the lung participate in protective humoral immune responses to pulmonary influenza virus reinfection. Proc Natl Acad Sci U S A 109: 2485-2490.

Osuka F, Endo Y, Higuchi M, Suzuki H, Shio Y, Fujiu K, Kanno R, Oishi A, Terashima M, Fujita T, Gotoh M (2007) Molecular cloning and characterization of novel splicing variants of human decayaccelerating factor. Genomics 88: 316-322.

Pang IK, Iwasaki A. Control of antiviral immunity by pattern recognition and the microbiome. Immun Rev 245: 209-226.

Pichlmair A, Lassnig C, Eberle CA, Górna MW, Baumann CL, Burkard TR, Bürckstümmer T, Stefanovic A, Krieger S, Bennett KL, Rülicke T, Weber F, Colinge J, Müller M, Superti-Furga G (2011) IFIT1 is an antiviral protein that recognizes 5'-triphosphate RNA. Nature Immunology 12: 624-630.

Price GE, Ou R, Jiang H, Huang L, Moskophidis D (2000) Viral escape by selection of cytotoxic T cell-resistant variants in influenza-A virus pneumonia. J Exp Med 191: 1853-1867.

Qi Y, Fan H, Qi X, Zhu Z, Guo X, Chen Y, Ge Y, Zhao K, Wu T, Li Y, Shan Y, Zhou M, Shi Z, Wang H, Cui L (2014) A novel pyrosequencing assay for the detection of neuraminidase inhibitor resistance-conferring mutations among clinical isolates of avian H7N9 influenza virus. Virus Research 179: 119-124.

Riberdy JM, Christensen JP, Branum K, Doherty PC (2000) Diminished primary and secondary influenza virus-specific CD8(+) T-cell responses in CD4-depleted $\mathrm{Ig}(-/-)$ mice. J Virol 74: 9762-9765.

Rimmelzwaan GF, Boon AC, Voeten JT, Berkhoff EG, Fouchier RA, Osterhaus AD (2004) Sequence variation in the influenza A virus nucleoprotein associated with escape from cytotoxic $\mathrm{T}$ lymphocytes. Virus Res 103: 97-100.

Rose MC, Voynow JA (2006) Respiratory tract mucin genes and mucin glycoproteins in health and disease. Physiol Rev 86: 245-278.

Sabbah A, Cheng TH, Harnack R, Frohlich V, Tominaga K, Dube PH, Xiang Y, Bose S (2009) Activation of innate immune antiviral responses by Nod2. Nature Immunol 10: 1073-1080.

Sambhara S, Kurichh A, Miranda R, Tumpey T, Rowe T, Renshaw M, Arpino R, Tamane A, Kandil A, James O et al. (2001) Heterosubtypic immunity against human influenza A viruses, including recently emerged avian $\mathrm{H} 5$ and $\mathrm{H} 9$ viruses, induced by FLU-ISCOM vaccine in mice requires both cytotoxic T-lymphocyte and macrophage function. Cell Immunol. 211: 143-153.

Schmitz N, Kurrer M, Bachmann MF, Kopf M (2005) Interleukin-1 is responsible for acute lung immunopathology but increases survival of respiratory Influenza virus infection. I Virol 79:6441-48.

Schnell JR, Chou JJ (2008) Structure and mechanism of the M2 proton channel of influenza A virus. Nature 45: 591-595.

Schotsaert M, de Filette M, Fiers , Saelens X (2009) Universal M2 ectodomain-based influenza A vaccines: Preclinical and clinical developments. Expert Rev Vaccine 8: 499-508.

Schulman JL, Kilbourne ED (1963) Transmission of influenza virus infection in mice. II. Some factors affecting the incidence of transmitted infection. J Exp Med 125: 479-488.

Shek LP, Lee BW (2003) Epidemiology and seasonality of respiratory tract virus infections in the tropics. Paediatr Respir Rev 4: 105-111.

Skehel J, Wiley DC (2000) Receptor binding and membrane fusion in virus entry: The influenza Hemagglutinin. Annu Rev Biochem 69: 531-569.

Shynia K, Ebina M, Yamada S, Ono M, Kasai N, Kawaoka Y (2006) Avian flu: Influenza virus receptors in the human airway. Nature 440: 435-436.

Simonsen L, Spreeuwenberg P, Lustig R, Taylor RJ, Fleming DM, Kroneman M, van Kerkhove MD, Mounts AW, Paget WA, the GlaMOR Collaborating Teams (2013) Global mortality estimates for the 2009 influenza pandemic from the GlaMOR Project: A modeling study. PLOS Medicine 10: (11)e1001558.

Sridhar S, Begom S, Bermingham A, Ziegler T, Roberts KL, Barclay WS, Openshaw P, Lalvani A (2012) Predominance of heterosubtypic IFN-gamma-only-secreting effector memory $\mathrm{T}$ cells in pandemic H1N1 naive adults. Eur J Immunol 2012: doi:10.1002/eji.201242504.

Sriwilaijaroen N \& Suzuki Y (2012) Molecular basis of the structure and function of $\mathrm{H} 1$ hemagglutinin of influenza virus. Proc Jpn Acad Ser B 88: 226-249.

Strutt TM, McKinstry KK, Dibble JP, Winchell C, Kuang Y, Curtis JD, Huston G, Dutton RW, Swain SL (2010) Memory CD4+ T cells induce innate responses independently of pathogen. Nat Med 16: $558-564$.

Su CTT, Schönbach C, Kwoh CK (2014) Molecuar docking analysis of 2009-H1N1 and 2004-H5N1 influenza virus HLA-B*4405-restricted HA epitope candidates: implications fot TCR cross-recognition and vaccine development. BMC Bioinformatics 14 (suppl 2): S21.

Sun X, Jayaraman A, Maniprasad P, Raman R, Houser KV, Pappas C, Zeng H, Sasisekharan R, Katz JM, Tumpey TM (2013) N-linked glycosylation of the hemagglutinin protein influences virulence and antigenicity of the 1918 pandemic and seasonal H1N1 influenza A viruses. J Virol 87: 8756-8766.

Tan SL, Katze MC (1998) Using genetic means to dissect homologous and heterologou protein-protein interactions of PKR, the Interferon-induced protein kinase. Methods 15: 207-223.

Teijaro JR, Turner D, Pham Q, Wherry EJ, Lefrancois L, Farber DL (2011) Cutting edge: Tissue-retentive lung memory CD4 T cells mediate optimal protection to respiratory virus infection. I Immunol 187: $5510-5514$.

Thakaramaran K, Raman R, Viswanathan K, Stebbins NW, Jayaraman A, Krishnan A, Sasisekharan V, Sasisekharan R (2012) Structural determinants for naturally evolving $\mathrm{H} 5 \mathrm{~N} 1$ hemagglutinin to switch its receptor specificity. Cell 153: 1475-1485.

Thakaramaran K, Jayaraman K, Raman R, Viswanathan K, Stebbins NW, Johnson D, Shriver Z, Sasisekharan V, Sasisekharan R (2013) Glycan receptor binding of the influenza A virus H7N9 hemagglutinin. Cell 153: 1486-1493.

The 1000 Genomes Consortium (2010) A map of human genome variation from population-scale sequencing. Nature 467: 1061-1073.

Throsby M, van den Brink E, Jongeneelen M, Poon LLM, Alard P, Cornelissen L, Bakker A, Cox F, van Deventer E, Guan Y, Cinatl J, ter Meulen J, Lasters I, Carsetti R, Peiris M, de Kruif J, Goudsmit J (2008) Heterosubtypic neutralizing monoclonal antibodies crossprotective against $\mathrm{H} 5 \mathrm{~N} 1$ and $\mathrm{H} 1 \mathrm{~N} 1$ recovered from human IgM+ Memory B cells. PloS ONE 3: (12)e3492.

Tompkins S M, Zhao Z S, Lo C Y, Misplon J A, Liu T, Ye Z, Hogan R J, Wu Z, Benton K A, Tumpey T M, et al. (2007) Matrix protein 2 vaccination and protection against influenza viruses, including subtype H5N1. Emerg Infect Dis 13: 426-435.

Tria F, Pompei S, Loreto V (2013) Dynamically correlated mutations drive human Influenza A evolution. Nature Scient Rep 3: 2705.

Tumpey TM, Basler CF, Aguilar PV, Zeng H, Solórzano A, Swayne DE, Cox NJ, Katz JM, Taubenberger JK, Palese P, García-Sastre A (2005) Characterization of the reconstructed 1918 Spanish influenza pandemic virus. Science 310: 77-80.

Uipraserktul M, Puthavathana P, Sangsiriwut K, Pooruk P, Srisook K, Peiris M, Nicholls JM, Chokephaibulkit K, Vanprapar N, Auewarakul P (2005) Influenza A H5N1 replication sites in humans. Emer Infect Dis 11: 1036-1041.

van den Brand JMA, Stittelaar KJ, van Amerongen G, Rimmelzwaan GF, Simon J, de Wit E, Munster V, Bestebroer T, Fouchier RAM, Kuiken T, Osterhaus ADM (2010) Severity of pneumonia due to new H1N1 influenza virus in ferrets is intermediate between that due to seasonal H1N1 virus and highly pathogenic influenza H5N1 virus. J Infec Dis 201: 993-999.

van Domselaar R, Bovenschen N (2011) Cell death-independent functions of granzymes: Hit viruses where it hurts. Rev Med Virol 21: $301-314$.

van Gisbergen KP, Klarenbeek PL, Kragten NA, Unger PP, Nieuwenhuis MB, Wensveen FM, ten Brinke A, Tak PP, Eldering E, Nolte MA, et al. (2011) The costimulatory molecule CD27 maintains clonally diverse CD8 $(+)$ T cell responses of low antigen affinity to protect against viral variants. Immunity 35: 97-108.

van Riel D, Leijten LM, van der Eerden M, Hoogsteden HC, Boven LA, Lambrecht BN, Osterhaus AD, Kuiken T (2011) Highly pathogenic avian influenza virus H5N1 infects alveolar macrophages without virus production or excessive TNF-alpha induction. PLoS Pathog 7: (6)e1002099.

Varki A, Gagneux P (2012) Multifarious roles of sialic acids in immunity. Ann N Y Acad Sci 1253: 16-36.

Viboud C, Alonso WJ, Simonsen L (2006) Influenza in tropical regions. PLoS Med 3:e89; doi:10.1371/journal.pmed.0030089.

Voeten JT, Groen J, van Alphen D, Claas EC, de Groot R, Osterhaus AD, Rimmelzwaan GF (1998) Use of recombinant nucleoproteins in enzyme-linked immunosorbent assays for detection of virus-specific immunoglobulin A (IgA) and $\operatorname{IgG}$ antibodies in influenza virus A- or B-infected patients. J Clin Microbiol 36: 3527-3531.

Voeten JT, Bestebroer TM, Nieuwkoop NJ, Fouchier RA, Osterhaus AD, Rimmelzwaan GF (2000) Antigenic drift in the influenza A virus (H3N2) nucleoprotein and escape from recognition by cytotoxic T lymphocytes. J Virol 74: 6800-6807.

von Itzstein M (2007) The war against influenza: discovery and development of sialidase inhibitors. Nat Rev Drug Disc 6: 967-974.

Voynow JA, Selby DM, Rose MC (1998) Mucin gene expression (MUC1, MUC2, and MUC5/5AC) in nasal epithelial cells of cystic friborsis, allergic rhinitis and normal individuals. Lung 176: 345-354. 
Waffarn EE, Baumgarth N (2011) Protective B cell responses to flu No fluke! I Immunol 186: 3823-3829.

Wagner R, Matrosovich M, Klenk HD (2002) Functional balance between haemagglutinin and neuraminidase in influenza virus infections. Rev Med Virol 12: 159-166.

Wallace RG and Fitch WM (2008) Influenza A H5N1 immigration is filtered out at some international borders. PLoS One 3: e1697.

Wang Y, Zhou L, Shi H, Xu H, Yao H, Xi X G, Toyoda T, Wang $\mathrm{X}$, Wang $\mathrm{T}$ (2009) Monoclonal antibody recognizing SLLTEVET epitope of M2 protein potently inhibited the replication of influenza A viruses in MDCK cells. Biochem Biophys Res Comm. 385: 118-122.

WHO - World Health Organization (http://www.who.int/en/ — last accessed on May $\left.9^{\text {th }}, 2014\right)$.

Wijburg OLC, Heemskerk MHM, Boog CJP, van Rooijen N (1997) Role of spleen macrophages in innate and acquired immune responses against mouse hepatitis virus strain A59. Immunology 92: 252-258.

Wilkinson TM, Li CK, Chui CS, Huang AK, Perkins M, Liebner JC, Lambkin-Williams R, Gilbert A, Oxford J, Nicholas B, et al. (2012) Preexisting influenza-specific CD4+ $T$ cells correlate with disease protection against influenza challenge in humans. Nat Med 18: 274 280 .

Worobey M, Guan-Zhu H, Rambaut A (2014) Genesis and pathogenesis of the 1918 pandemic H1N1 influenza A virus. Proc Nat Acad Sci 111: 8107-8112.
Yang ML, Chen YH, Wang SW, Huang YJ, Leu CH, Yeh NC, Chu CY, Lin CC, Shieh GS, Chen YL, Wang JR, Wang CH, Wu CL, Shiau AL (2011) Galectin-1 binds to influenza virus and ameliorates influenza virus pathogenesis. J Virol 85: 10010-10020.

Yang Z, Huffman FL (2013) Nutrition in pregnancy and early childhood and associations with obesity in developing countries. Maternal and Child Nutrition 9 (Suppl 1) 105-119.

Yu X, Tsibane T, McGraw P A, House F S, Keefer C J, Hicar M D, Tumpey, T M, Pappas C, Perrone L A, Martinez O, et al (2008) Neutralizing antibodies derived from the B cells of 1918 influenza pandemic survivors. Nature 455: 532-536.

Zhou J, To KKW, Dong H, Cheng ZS, Lau CCY, Poon VKM, Fan YH, Song YQ, Tse H, Chan KH, Zheng BJ, Zhao GP, Yuen KY (2012) A functional variation in CD55 gene increases the disease severity of pandemic A(H1N1)2009 influenza infection. I Infect Dis 206: 495-503.

Zhu J, Paul WE (2010a) Heterogeneity and plasticity of T helper cells. Cell Res 20: 4-12.

Zhu J, Paul WE (2010b) Peripheral CD4+ T-cell differentiation regulated by networks of cytokines and transcription factors. Immunol Rev 238: 247-262.

Zimmermann C, Prevost-Blondel A, Blaser C, Pircher H (1999) Kinetics of the response of naive and memory CD8 $\mathrm{T}$ cells to antigen: Similarities and differences. Eur J Immunol 29: 284-290. 